\title{
Preliminary Assessment of Existing Experimental Data for Validation of Reactor Physics Codes and Data for NGNP Design and Analysis
}

prepared by

Nuclear Engineering Division

Argonne National Laboratory 


\section{About Argonne National Laboratory}

Argonne is managed by The University of Chicago for the U.S. Department of Energy under contract W-31-109-Eng-38. The Laboratory's main facility is outside Chicago, at 9700 South Cass Avenue, Argonne, Illinois 60439. For information about Argonne and its pioneering science and technology programs, see www.anl.gov.

\section{Availability of This Report}

This report is available, at no cost, at http://www.osti.gov/bridge. It is also available on paper to U.S. Department of Energy and its contractors, for a processing fee, from:

U.S. Department of Energy

Office of Scientific and Technical Information

P.O. Box 62

Oak Ridge, TN 37831-0062

phone (865) 576-8401

fax (865) 576-5728

reports@adonis.osti.gov

\section{Disclaimer}

This report was prepared as an account of work sponsored by an agency of the United States Government. Neither the United States Government nor any agency thereof, nor The University of Chicago, nor any of their employees or officers, makes any warranty, express or implied, or assumes any legal liability or responsibility for the accuracy, completeness, or usefulness of any information, apparatus, product, or process disclosed, or represents that its use would not infringe privately owned rights. Reference herein to any specific commercial product, process, or service by trade name, trademark, manufacturer, or otherwise, does not necessarily constitute or imply its endorsement, recommendation, or favoring by the United States Government or any agency thereof. The views and opinions of document authors expressed herein do not necessarily state or reflect those of the United States Government or any agency thereof, Argonne National Laboratory, or The University of Chicago. 


\section{Preliminary Assessment of Existing Experimental Data for Validation of Reactor Physics Codes and Data for NGNP Design and Analysis}

by

W.K. Terry, J.K. Jewell, and J. Blair Briggs

Idaho National Engineering and Environmental Laboratory

T.A. Taiwo, W.S. Park, and H.S. Khalil

Nuclear Engineering Division, Argonne National Laboratory

September 15,2004

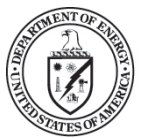




\section{Table of Contents}

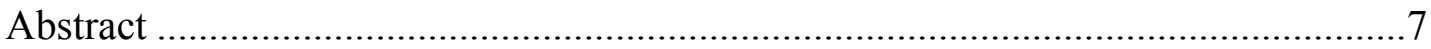

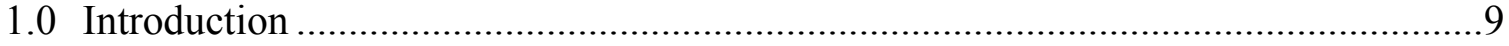

2.0 Assessments of Reactor Physics Facilities/Experiments for the Pebble-Bed

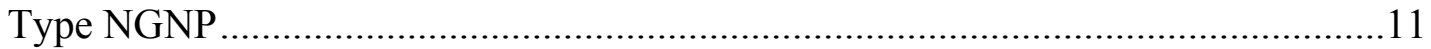

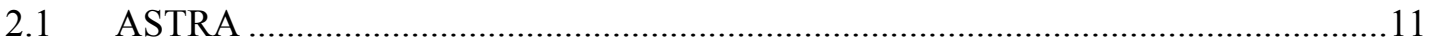

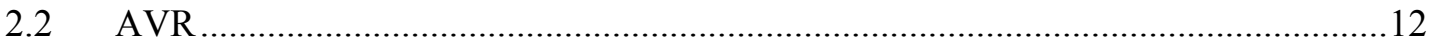

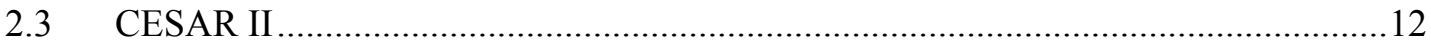

2.4 GROG

$2.5 \quad$ HTR-10

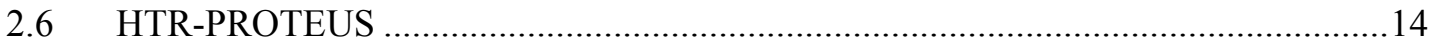

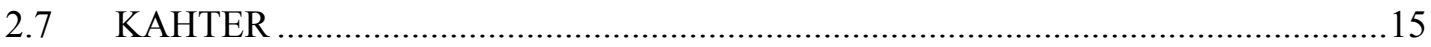

2.8 SAR

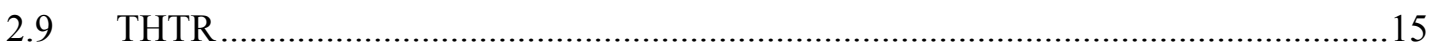

3.0 Assessments of Reactor Physics Facilities/Experiments for the Prismatic-Block-

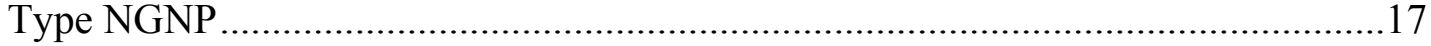

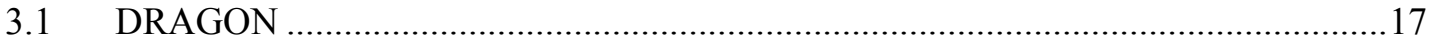

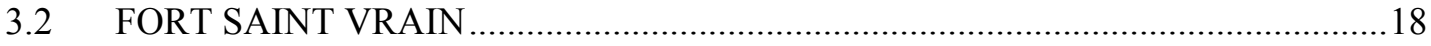

3.3 GULF GENERAL ATOMIC HTGR CRITICAL EXPERIMENTS .........................19

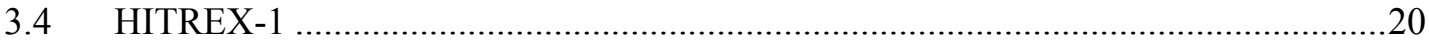

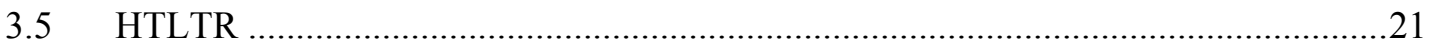

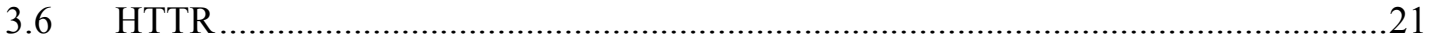

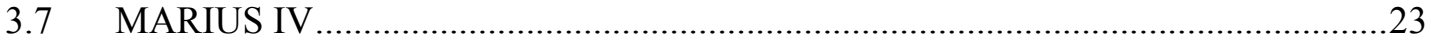

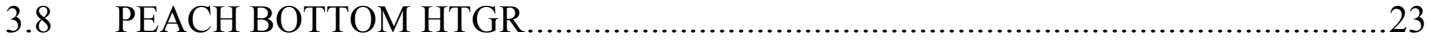




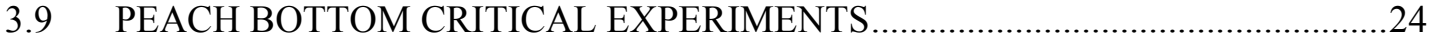

3.10 SHE

3.11 UKAEA ENRICHED HTTR LATTICES (NESTOR/HECTOR) ............................26

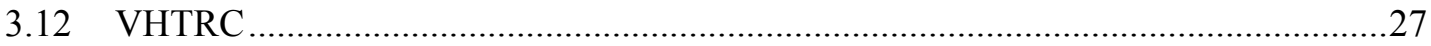

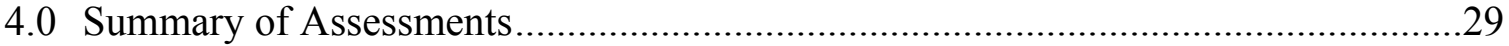

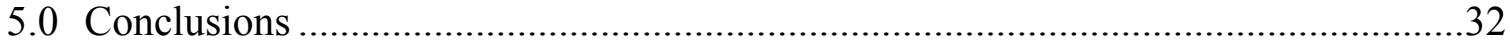

APPENDIX A Assessment of Experiments for Pebble-Bed Reactor Physics Code Benchmarking ........................................................................ 33

APPENDIX B Assessment of Experiments for Prismatic-Block-Type Reactor Physics Code Benchmarking 


\section{List of Tables}

Table 1. NGNP Core Design Description .................................................................

Table 2. Comparison of Facilities Relevant to Codes for Modeling Pebble-Bed-Type Core. .30

Table 3. Comparison of Facilities Relevant to Codes for Modeling Prismatic Block Type Core 


\begin{abstract}
The Next Generation Nuclear Plant (NGNP), a demonstration reactor and hydrogen production facility proposed for construction at the INEEL, is expected to be a hightemperature gas-cooled reactor (HTGR). Computer codes used in design and safety analysis for the NGNP must be benchmarked against experimental data. The INEEL and ANL have examined information about several past and present experimental and prototypical facilities based on HTGR concepts to assess the potential of these facilities for use in this benchmarking effort. Both reactors and critical facilities applicable to pebble-bed and prismatic block-type cores have been considered.

Four facilities - HTR-PROTEUS, HTR-10, ASTRA, and AVR - appear to have the greatest potential for use in benchmarking codes for pebble-bed reactors. Similarly, for the prismatic block-type reactor design, two experiments have been ranked as having the highest priority - HTTR and VHTRC.
\end{abstract}




\subsection{Introduction}

The Next Generation Nuclear Plant (NGNP), a combined electric power and hydrogen production prototype facility of the high-temperature gas-cooled reactor (HTGR) type proposed for construction at the INEEL, will be a significant step forward from HTGRs built and operated to date. It will not only produce high power (at least $600 \mathrm{MWt}$ ), but it will also be passively safe: no postulated accident will require any operator intervention to prevent fuel damage. This combination has not been achieved in any previously built HTGR. The NGNP may be either a pebble-bed reactor (PBR) or use prismatic (block) fuel; if it is a PBR, the NGNP will also be significantly different in design from previous reactors of that type, with an annular rather than a cylindrical core. Table 1 summarizes the general characteristics of the prismatic block-type and pebble-bed-type NGNPs.

Table 1. NGNP Core Design Description.

\begin{tabular}{|c|c|c|}
\hline Parameter & Block-Type NGNP & Pebble-Bed NGNP \\
\hline Core General & $\begin{array}{l}\text { - Long slender annular type } \\
\text { - Low power density }\left(\sim 6.5 \mathrm{~W} / \mathrm{cm}^{3}\right) \\
\text { - Fixed burnable absorber } \\
\text { - Graphite moderation } \\
\text { - Helium cooling } \\
\text { - High outlet temperature } \\
\quad\left(1,000{ }^{\circ} \mathrm{C}\right) \\
\text { - Independent coolant channel (no } \\
\text { direct contact of the coolant } \\
\text { with fuel compacts) }\end{array}$ & $\begin{array}{l}\text { - Long slender annular type } \\
\text { - Low power density }\left(\sim 4 \mathrm{~W} / \mathrm{cm}^{3}\right) \\
\text { - Constant core due to online } \\
\quad \text { refueling } \\
\text { - Graphite moderation } \\
\text { - Helium cooling } \\
\text { - High outlet temperature } \\
\quad\left(1,000{ }^{\circ} \mathrm{C}\right)\end{array}$ \\
\hline Fuel & $\begin{array}{l}-<20 \% \text { enriched U-235 } \\
\text { - Single TRISO fuel (fissile) } \\
\text { - Fuel compacts in fuel element } \\
\text { - Discharged at }>100 \mathrm{GWd} / \mathrm{MTU}\end{array}$ & $\begin{array}{l}\text { - 8 9\% enriched U-235 } \\
\text { - Single TRISO fuel (fissile) } \\
\text { - Pebble type } \\
\text { - Discharged at } \sim 80 \mathrm{GWd} / \mathrm{MTU} \\
\text { (highly uniform discharged } \\
\text { burnup) }\end{array}$ \\
\hline Control Rods & $\begin{array}{l}\text { - Installed in both fuel block and } \\
\text { reflector regions }\end{array}$ & - Installed only in reflector regions \\
\hline
\end{tabular}

As evident in Table 1, the current designs for the block-type and pebble-bed-type NGNP have common features such as (1) low enriched uranium (LEU) fuel, (2) annular core, (3) control rods located in the core and/or in the side reflector, (4) and high effective heightto-diameter (H/D) ratio. This suggests that some experimental data generated for one type might be used in the code validation basis of the other type. The experimental dataset should allow the validation of predictions on parameters such as

o Core criticality (for representative $\mathrm{C} / \mathrm{U}$ ratio, enrichment, fuel particle parking fraction )

o Temperature coefficients (at cold and hot conditions)

o Control rod worths (within core and reflector) 
o Power distributions (including impact of burnable poisons and control rods on the power distribution)

o Reaction rates

o Water ingress (effect on reactivity, temperature coefficients, and rod worths)

o Decay heat

- Reactor transients

o Reactor shielding.

Computer codes used in design and safety analyses of the NGNP must be shown a priori to be able to model NGNP configurations accurately. Therefore, these codes must be benchmarked against appropriate available experimental data. Various experimental data on the reactor physics of high-temperature reactors (HTRs) have been obtained internationally since the early 1960s. During FY-04, the INEEL and ANL have studied all the known experimental and prototypical HTGRs and relevant critical facilities in order to assess their potential to be used as benchmarks. The INEEL reviewed facilities of the pebble-bed type, with one exception: the Fort St. Vrain block-type reactor was also studied by the INEEL. ANL primarily reviewed block-type facilities, but also studied the HTR-PROTEUS facility, which has been configured as a pebble-bed critical facility.

This report describes the assessments and identifies facilities most likely to be suitable for benchmarking codes to be used for the design and analysis of the NGNP (pebble-bed or prismatic-block type). Sections 2.0 and 3.0 contain brief descriptions of the experiments/facilities that have been assessed. Section 2.0 contains information on experiments relevant to pebble-bed cores, while Section 3.0 contains descriptions of experiments related to prismatic-block-type cores. A summary of the assessments is presented in Section 4.0. Conclusions from the study are presented in Section 5.0. 


\subsection{Assessments of Reactor Physics Facilities/Experiments for the Pebble-Bed Type NGNP}

The facilities that have been assessed for the pebble-bed type NGNP are ASTRA, AVR, CESAR II, GROG, HTR-10, HTR-PROTEUS, KAHTER, SAR, and THTR. Each of these facilities and its assessment are discussed below. The complete assessments are attached as Appendix A.

\subsection{ASTRA}

ASTRA is a zero-power critical facility located at the Kurchatov Institute in Russia. It has been configured to represent a PBR core for the South African company PBMR (Pty.) Ltd., which is developing a PBR for domestic power production and foreign sales. As so configured, it has an important distinction from most of the other pebble-bed critical facilities that were assessed: it has an annular core. A central region of pure graphite pebbles represents the inner reflector, an outer zone of fuel pebbles represents the core, and a zone of mixed fuel and pure graphite pebbles separates the inner reflector and core zones. The original conception of the South African PBMR was actually configured in this way. Pure graphite pebbles were to be dropped into the central zone, fuel pebbles were to be dropped into the outer zone, and a region containing both types of pebble would naturally develop between those zones because there was to be no barrier between them. However, coolant flow through the unheated inner reflector pebbles would have exacted too great a penalty in thermodynamic efficiency, so the inner reflector is solid in current PBMR designs.

Furthermore, ASTRA is currently operating. Its status as an operating facility presents the possibility of performing further experiments to obtain more data, if existing data are not adequate to permit a thorough benchmarking effort. Fuel specifications could also be changed; currently its fuel is the standard low-enriched TRISO fuel planned for the PBMR. Its annular core is more similar to the proposed NGNP configuration than the cylindrical cores in the other assessed PBRs and pebble-bed critical facilities.

The ASTRA core is not azimuthally symmetric: its inner boundary is cylindrical, but its outer boundary has an octagonal cross section in the horizontal plane. Past, present, and planned PBR cores have cylindrical boundaries, and codes written for PBRs (e.g., PEBBED and VSOP) are formulated in cylindrical geometry. The Monte Carlo code MCNP, which has some usefulness for PBR physics analysis, has no such restriction, but in general, the octagonal outer boundary must be approximated as a cylinder.

As configured for PBR experiments performed for PBMR, the ASTRA core has an equivalent outside diameter of $1.81 \mathrm{~m}$ and a depth of $2.7 \mathrm{~m}$. The core inside diameter (i.e., the outside diameter of the mixing zone) is $1.06 \mathrm{~m}$. Thus, the core thickness is about $0.37 \mathrm{~m}$. These dimensions are small compared to the core in the NGNP designs.

The advantages of ASTRA are deemed to outweigh the shortcomings, and ASTRA has been assigned a high priority for evaluation as an NGNP benchmark facility. Some 
benchmarking of MCNP against ASTRA data has already been accomplished. The PBMR company is engaged in benchmarking VSOP against ASTRA.

\subsection{AVR}

The conception of Professor Rudolf Schulten, the German AVR (Arbeitsgemeinschaft Versuchsreaktor, meaning a test reactor built by an association), was a prototype PBR that operated for over 21 years, beginning in August 1966. It was built at Forschungszentrum Jülich (FZJ) and provided a great deal of operating experience and experimental data, including some accident simulation data. It used a variety of fuel pebbles, which eventually evolved into the TRISO pebbles that will be used in the NGNP.

While a good deal of the data obtained from AVR can be found in archival journals, much of the information needed for benchmarking is contained in FZJ laboratory reports. Attempts to date to obtain those reports have not been successful. One suspects that the right contacts, and the offer to pay for the reports, might bring better results.

AVR was a low-power reactor (46 MWt) with a cylindrical core. Its core was $3 \mathrm{~m}$ in diameter and $2.8 \mathrm{~m}$ high, which is a large volume for such a low power output. The PBR NGNP would have a tall core (about $10 \mathrm{~m}$ high) with a rather narrow radial thickness (about $1 \mathrm{~m}$ ) in order to provide a short thermal transport length for heat rejection in an accident, so the NGNP neutron spectrum may be significantly different from that in AVR. Furthermore, the final TRISO fuel particles with low-enriched uranium were not introduced into AVR until 1982, so it is possible that earlier data apply to neutron energy spectra not well matched to the spectrum in the NGNP.

Because of the great amount of experimental data that were obtained during the life of AVR, this reactor is considered one of the most promising sources of benchmark data for NGNP design and safety analysis codes.

\subsection{CESAR II}

CESAR II was an experimental critical facility located in France and managed collaboratively between the CEA/Cadarache and KFA/Jülich between 1964 and 1974. CESAR II was converted to a pebble-bed reactor by replacing the central CESAR core with spherical fuel elements. In the experiment cavity, a $1 \mathrm{~m}$ bed of pure graphite pebbles, equal in size $(6 \mathrm{~cm}$ in diameter) to the fuel pebbles, was laid at the bottom. The actual core height was $2 \mathrm{~m}$. On top of that, another $1 \mathrm{~m}$ layer of pure graphite pebbles was placed. The original outer reflector zones were retained in the pebble bed implementation.

The CESAR II facility conducted extensive comparisons between modeling and fission foil experimental results by a variety of methods.

CESAR II achieved a realistic fuel element packing fraction of $61 \%$. 


\subsection{GROG}

GROG is a critical facility located at the Kurchatov Institute in Russia. It consists of a set of graphite blocks stacked in a cubic arrangement, with nine vertical channels in each block. The channels in vertically adjacent blocks are aligned, so that the channels are continuous through the vertical height of the core. Various kinds of fuel elements, including PBR-type pebbles, can be placed in the channels. By choosing which channels to fill with fuel and which to fill with graphite or other rods, one can approximate a wide variety of core geometries, including cylindrical or annular pebble-bed cores.

GROG has been operating since 1980, and it is available for further experimental programs.

However, the arrangement of the fuel pebbles in stacks in the channels leads to some significant differences from actual PBR cores. The packing fraction of pebbles in a real PBR core is about $61 \%$, while in GROG it is certainly much lower. This difference is likely to produce significantly different neutron energy spectra in GROG and the NGNP.

GROG is considered to have medium potential for NGNP code benchmarking.

\subsection{HTR-10}

HTR-10 is a currently operating experimental PBR at the Tsinghua University in the People's Republic of China. It first achieved criticality in December 2000. It is a lowpower facility $(10 \mathrm{MWt})$, with a core diameter of $1.8 \mathrm{~m}$ and a core height of $1.97 \mathrm{~m}$. Its core is cylindrical. Thus, it may have spectral differences from the NGNP similar to those expected for AVR. However, unlike AVR, it is currently operating, so it is feasible to obtain data needed for benchmarking that do not currently exist.

After an initial transient period of several months, a PBR will develop a steady-state (asymptotic) distribution of compositions and neutron flux. The INEEL code PEBBED finds this asymptotic state directly, and the German code VSOP, currently the standard PBR reactor physics analysis tool, models the evolution of the asymptotic state in time. For both codes, experimental data on the asymptotic state are necessary for benchmarking. HTR-10 appears to be the most likely facility for providing these experimental data. Even if HTR-10 and the NGNP differ significantly in their neutron spectra, HTR-10 can provide important confirmation that PEBBED and VSOP can calculate the asymptotic state accurately for a real PBR.

HTR-10 is assigned the highest priority for a full evaluation. Some benchmarking of the code MCNP has already been accomplished for the fresh HTR-10 core at its initial criticality. 


\subsection{HTR-PROTEUS}

The HTR-PROTEUS experiments were performed in the 1990s under an IAEA Coordinated Research Project (CRP) on Validation of Safety Related Physics Calculations for Low Enriched High-Temperature Gas-Cooled Reactors (HTGRs). The purpose of the experiment was to enhance confidence in predictions of neutron physics behavior of the HTGRs by filling gaps in validation data for physics methods used for core design of gas-cooled reactors fueled with low enriched uranium (LEU). Under the auspices of the CRP, an international team of researchers was assembled at the PROTEUS critical experiment facility of the Paul Scherrer Institut (PSI), Switzerland, to plan, conduct and analyze a new series of critical experiments focused on the needs of the participating countries. [1] These experiments are valuable because they complement those obtained in earlier years for highly enriched HTR systems such as the pebble-bed investigations at the KAHTER facility in Germany, the prismatic-block experiments at General Atomics and Battelle Northwest Laboratory, the low enrichment HTR lattice at Winfrith in England, and the LEU experiments in the VHTRC facility in Japan.

In PROTEUS, critical experiments were conducted for graphite-moderated LEU systems to determine core reactivity, flux and power profiles, reaction-rate ratios, the worth of both in-core- and reflector-based control rods, the worth of burnable poisons, kinetics parameters, and the effects of moisture ingress on these parameters. Fuel for the experiments was provided by the KFA Research Center, Jülich, Germany; 5500 LEU fuel pebbles were made available to the experiment. Initial criticality was achieved on July 7 , 1992. These experiments were conducted over a range of experimental parameters such as carbon-to-uranium ratio, core height-to-diameter ratio, and simulated moisture concentration. [1]

The PROTEUS facility consists of a graphite cylinder $3.26 \mathrm{~m}$ in diameter and $3.3 \mathrm{~m}$ in height, with a central "cylindrical" cavity (the horizontal cross section is actually in the form of a 22-sided polygon) $1.25 \mathrm{~m}$ in diameter (flat-to-flat) and about $1.7 \mathrm{~m}$ in height, located $0.78 \mathrm{~m}$ above the bottom reflector of the system. The top of the system has a graphite reflector. The system has eight boron-steel shutdown rods, situated at a radius of $0.68 \mathrm{~m}$, and four fine stainless steel control rods located at a radius of $0.9 \mathrm{~m}$. The experiments were characterized by clean critical cores using LEU (16.76 w/o U-235) pebble-type fuel and pure graphite moderator pebbles. The carbon-to-uranium $(\mathrm{C} / \mathrm{U})$ atom ratio ranged from 946 to 1890 ; a desired ratio was achieved by varying the moderator-to-fuel pebble ratio from 0 . to 2.0 .

The HTR-PROTEUS experimental data are rated high and should be valuable to the validation and verification of design methods for pebble-type NGNP analysis. The experimental facility should also be useful to any international effort devoted to such goals, particularly since the personnel that contributed to these experiments are still available.

\section{Reference}

1. "Critical Experiments and Reactor Physics Calculations for Low-Enriched High Temperature Gas-Cooled Reactors,” IAEA TECDOC-1249, Vienna, 2001. 


\subsection{KAHTER}

KAHTER was a critical facility specifically designed for benchmarking codes that model PBRs. It was built to represent AVR and THTR (discussed below) at Jülich, and it achieved first criticality in 1973. Its core was a cylinder $2.16 \mathrm{~m}$ in diameter and up to $2.76 \mathrm{~m}$ in height.

A wealth of data from KAHTER exists that could be used for benchmarking computer code models of fresh cores. However, as a critical facility, KAHTER did not obtain data on the asymptotic states, so the ability of PEBBED and VSOP to predict asymptotic states cannot be assessed with data from KAHTER. Moreover, since AVR did not use modern low-enriched TRISO fuel particles until 1982, much of the KAHTER data from before that time may not be well matched spectrally to the NGNP.

KAHTER is assigned high priority for NGNP code benchmarking, but not as high as AVR and HTR-10, which, as operating power reactors, achieve an asymptotic state.

\subsection{SAR}

SAR, the Siemens-Argonaut Reactor at the Technische Universität Graz, in Austria, was modified to perform experimental evaluations of a specific safety issue, the consequences of water ingress into a pebble-bed reactor core. SAR comprises a central cylindrical experiment zone within an annular core containing plate fuel elements similar to those in the INEEL's Advanced Test Reactor (ATR), except that the plates in SAR are not curved. The SAR fuel elements are rectangular in cross section, and adjacent fuel elements are separated by wedge-shaped graphite segments. Thus, SAR is slightly asymmetric azimuthally.

For the water ingress experiments, the central experiment zone was filled with AVR-type fuel pebbles (the type is not stated in the source paper, but from the publication date of 1986, one infers that they were based on low-enrichment TRISO fuel particles) and then filled with varying quantities of polyethylene and polystyrol granules to represent water by their hydrogen content. Measurements were made of k-effective and neutron flux profiles in seven energy groups.

SAR has limited usefulness in benchmarking codes to be used for NGNP reactor physics. However, the water ingress accident is a concern in PBRs, and in fact, such an accident occurred in AVR. Therefore, SAR may have a role in validation of PBR reactor physics codes. For now, it is assigned a low priority.

\subsection{THTR}

The German Thorium High-Temperature Reactor (THTR) was a large power plant reactor based on a thorium-uranium fuel cycle. Its core diameter was $5.6 \mathrm{~m}$, its core height was $6 \mathrm{~m}$, and it produced $760 \mathrm{MWt}$ and $307 \mathrm{MWe}$ of power. It employed a crude 
but effective control system in which control rods were pushed down into the pebble bed, displacing pebbles as they went. Not surprisingly, the control rods did some damage to pebbles, but after they were modified, that problem was greatly reduced.

THTR operated from 1987 to 1989 . It was shut down because of "institutional issues," which may be interpreted as a reaction to a surge of antinuclear public sentiment in Germany that rose at about that time. The Chernobyl accident occurred in 1986.

THTR was intended to be a power plant, not an experimental facility. Thus, only limited data were obtained while it was operating at power. However, more measurements were made at zero power during initial checkout and startup.

Because of the different fuel type and the different core geometry in THTR from those planned for the NGNP, data from THTR is not likely to be a good match for benchmarking NGNP codes. It is assigned medium priority. 


\subsection{Assessments of Reactor Physics Facilities/Experiments for the Prismatic-Block-Type NGNP}

The facilities that have been assessed for the prismatic block type NGNP are DRAGON, Fort St. Vrain, Gulf General Atomic (GGA) criticals, HITREX-1, HTLTR, HTTR, MARIUS IV, the Peach Bottom Reactor, Peach Bottom criticals, SHE, U.K. NESTOR and HECTOR lattices, and VHTRC. Each of these facilities and its assessment are discussed below. The complete assessments are attached as Appendix B.

\subsection{DRAGON}

The Dragon Reactor Experiment (DRE) in the United Kingdom was a facility used for irradiation testing of fuels and fuel elements, and for technological tests of components and materials utilized in a number of high-temperature reactor (HTR) projects pursued in the 1960s and 1970s. The DRE was built and managed as an OECD/NEA international joint project and operated between 1964 and 1975. In addition to testing fuel for itself, the DRAGON facility was used to support the development of the THTR, the Fort St. Vrain high-temperature gas-cooled reactor (HTGR), and other HTR designs.

The DRAGON core consisted of thirty-seven fuel elements, placed in a hexagonal array with an effective diameter of $1.08 \mathrm{~m}$. This hexagonal array was surrounded by 30 prismatic graphite columns of the inner reflector, machined on one side to match the profile of the adjacent fuel element and on the other to form a circle $1.5 \mathrm{~m}$ in diameter. The inner reflector was surrounded by an outer fixed radial reflector. Twenty-four control rods operated in holes in the inner reflector. The overall length of a fuel element was $2.54 \mathrm{~m}$, of which $1.60 \mathrm{~m}$ in the middle contained fuel. The remaining lengths at the top and bottom comprised the axial reflector and end fittings. The helium coolant entered the core from below and passed upward through channels between fuel rods. Maximum thermal power was $21.5 \mathrm{MW}$, obtained with an inlet temperature of $350{ }^{\circ} \mathrm{C}$, an outlet temperature of $750{ }^{\circ} \mathrm{C}$, and a helium mass flow rate of $9.62 \mathrm{~kg} / \mathrm{s}$ at $20 \mathrm{~atm}$.

DRAGON was not designed as a reactor physics experimental facility. However, a wide variety of zero-power and at-power experiments was performed to confirm the understanding of the physics of the reactor, both to assure the safety committee that fuelloading procedures were sound and to ensure that core planning was based on firm experimental evidence. Experiments performed included measurement of excess reactivity and rod worths in cold and hot conditions at the beginning and end of core lives, measurements of temperature coefficients (isothermal temperature coefficients), U235 and $\mathrm{Pu} / \mathrm{U}$ fission rates, fast fission rates, relative conversion ratios, reactivity effect of water ingress (by insertion of hydrogenous material in fuel element), transient tests (reactor response to changes in plant conditions), and graphite damage rate tests.

The DRE itself presented special problems, as it was physically small for a graphitemoderated system and had high neutron leakage $(\sim 30 \%)$. Because the thermal neutron peaks were in the reflector, this region played a very significant role in the neutron 
balance. As a result, the reactor was controlled by absorbers inserted in the reflector. Calculations of the reaction rate distributions in the DRAGON core were difficult because of the small core size and the irregular nature of the core.

The initial planning for the DRE was for a highly enriched uranium (HEU) and thorium system. However, when it became evident that commercial interest in such systems was tempered by doubts over the long-term availability of HEU and concerns over the lack of large-scale reprocessing facilities for thorium fuels, the Dragon project turned to the use of low enriched uranium for HTRs.

It is unclear whether useful data can be retrieved from the DRAGON project, since the experiments ended about 30 years ago. The DRAGON facility was, however, developed based on previous HTR designs of the block type, so the conditions do not fully represent those in the NGNP. It is therefore rated medium.

\section{References:}

1. R.A. Simon and P.D. Capp, "Operating Experience with the DRAGON High Temperature Reactor Experiment," HTR-2002, Proceedings of the Conference on High Temperature Reactors, Petten, NL, April 22-24, 2002, Reproduced by the IAEA Vienna, Austria, 2002.

2. J. P. H. Blake, V.E. Della Loggia, J. Reber, "Physics Experiments on the Dragon Reactor Experiment," D. P. Report 166, May 1963. (Obtained from CD containing OECD Dragon Project Reports, NEA-1726/01.)

3. I. R. Cameron et al., "Measurements of Control Rod Worth and Excess Reactivity on the First Core of Dragon”, D. P. Report 359, July 1965. (Obtained from CD containing OECD Dragon Project Reports, NEA-1726/01.)

4. V. E. Della Loggia et al., "Zero Energy Experiments on the Dragon Reactor Prior to Charge IV Startup", D. P. Report 820, Jan. 1973. (Obtained from CD containing OECD Dragon Project Reports, NEA-1726/01.)

5. DRAGON Project \& its Contribution to the Development of the High Temperature Reactor (HTR)," D. P. Report 1000, November 1978. (Obtained from CD containing OECD Dragon Project Reports, NEA-1726/01.)

\subsection{FORT SAINT VRAIN}

The Fort Saint Vrain (FSV) reactor was designed to produce a power of $842 \mathrm{MWt}$ (330 MWe). Initial core criticality was achieved in January 1974. The active core was approximately a right circular cylinder with an equivalent diameter of $5.9 \mathrm{~m}$ and a vertical height of $4.8 \mathrm{~m}$. The active core was surrounded by graphite reflectors. The active core was made up of 247 fuel columns with six individual fuel elements vertically stacked in each column. Each fuel element (prismatic hexagonal block) had a height of $79.2 \mathrm{~cm}$ and an across-flat width of $38.6 \mathrm{~cm}$.

The fuel was contained in the graphite elements as blended beds of coated fuel particles and coke filler. The fresh fuel materials were highly enriched uranium (HEU) and fertile 
thorium in carbide form. The ratio of thorium to uranium was about 10 . The reactor was controlled by lumped burnable poison (LBP) in the form of $\mathrm{B}_{4} \mathrm{C}$ rods and control rods.

At FSV, a series of zero power measurements was performed with air in the core and with special instrumentation and materials (high sensitivity $\mathrm{BF}_{3}$ detectors, low-strength neutron source, temporary in-core poison), which were removed prior to sealing of the reactor and filling with helium. Rise-to-power and at-power tests were also performed. Physics parameters measured included core criticality, rod worths, shutdown margins, isothermal temperature coefficients, and axial flux distributions. Fuel burnup data were also collected from destructive post-irradiation examination of special fuel elements.

The FSV data are quite relevant to the validation of data and tools for analysis of large high-temperature gas-cooled reactors. However, the usefulness to the NGNP design is rather limited because the measurements were for a thorium fuel cycle and the core had no central reflector zone. Therefore, it is ranked medium/high.

\section{Reference:}

1. J. R. Brown et al., "Physics Testing at Fort St. Vrain - A Review," Nucl. Sci. Eng., 97, 104 (1987).

\subsection{GULF GENERAL ATOMIC HTGR CRITICAL EXPERIMENTS}

In the late 1960's the Gulf General Atomic (GGA) company engaged in a series of critical experiments designed to provide necessary technical background information for the continued development of large high-temperature gas-cooled reactor (HTGR) systems. The experimental data were used in evaluating cross-section data that were employed by GGA for the design of HTGRs. In the experiments, the reactivity worths of materials were measured; materials investigated were U-233, U-235, U-236, U-238, Np237, Th-232, $\mathrm{Pu}-239, \mathrm{Pu}-240$, and boron. Other lattice parameters that were measured included core criticality, Doppler coefficients, control rod worth, reactivity worth of burnable poisons, and flux plots in a central part of a critical facility that simulated the HTR block fuel geometry.

The Modified Critical Facility was used for the experiments. The critical assembly consisted of an array of $4.2 \mathrm{~cm}$ thick-walled aluminum tubes welded into a honeycomb structure and mounted on a split-bed assembly machine. [1] The tubes contained fuel compacts made of highly enriched uranium-graphite in the form of $\mathrm{U}_{3} \mathrm{O}_{8}$. The fuel in the so-called exact core region (central tubes) was in the form of $\mathrm{U}_{2} \mathrm{O}$. The HEU enrichment was 93 w/o U-235. Cores having both thermal and hard spectra were constructed, with $\mathrm{C} / \mathrm{U}-235$ ratios in the range 5,000 to 432 . The overall dimensions of the fully integrated split beds were $213 \mathrm{~cm}$ by $183 \mathrm{~cm}$ by $183 \mathrm{~cm}$ (they consisted of two halves). The core reflector was made of graphite. No axial reflector was utilized. A cylindrical core geometry was used in the experiments so that one-dimensional codes could be used for analyzing the experiments. An extensive description of the core contents, dimensions, and measurement methods and results is provided in Reference 1. A representative calculational model for the core can be developed from those data. 
The HTGR criticals present a clean experiment against which core analysis models and data could be validated. The criticals, however, use HEU fuel. The critical experiments use a cylindrical core as opposed to the annular core used in the NGNP designs. For these reasons, the usefulness of the critical experiments to the NGNP is rated medium/high.

\section{Reference:}

1. R. G. Bardes, et al., "Results of HTGR Critical Experiments Designed to Make Integral Checks on the Cross Sections in Use at Gulf General Atomic," GA-8468, GA Technologies, Inc., (Feb. 1968).

\subsection{HITREX-1}

A series of reactor physics experiments was performed with the CEGB zero energy HTR facility HITREX-1 at the Berkeley Nuclear Laboratories in the 1960s and early 1970s. The objective was to provide experimental tests that could be used for assessment of the validity and accuracy of the calculational methods proposed for HTR design and operation. The project activities included activation measurements to determine power distributions, assessments of control rod effects (reactivity worths and core perturbations), measurements of flux distributions, investigation of $\mathrm{Pu}-239$ production and impact on fuel burnup and reactivity coefficients, and measurements of fission rate of $\mathrm{Pu}-239$ relative to $\mathrm{U}-235$.

HITREX-1 was a two-zone reactor based on a hexagonal fuel block. The central region was fueled with 174 fuel channels of teledial fuel $2 \mathrm{~m}$ in height. This zone was surrounded by 312 channels of annular compact fuel of the same height. The core arrangement was equivalent to a 27-block column core having 18 fuel channels per block. The core was surrounded axially and radially by solid graphite reflector. [1]

The teledial fuel element, which could be 50 or $25 \mathrm{~cm}$ long, consisted of a hollow graphite cylinder in which are drilled eight holes of $1.27 \mathrm{~cm}$ diameter each. Fuel compacts $5 \mathrm{~cm}$ long were inserted in each hole. The annular fuel elements had similar lengths to the teledial elements, but consisted of two hollow graphite cylindrical cans sandwiching a zone containing the fuel compacts. The fuel compact in the teledial element had an enrichment of $3.5 \mathrm{w} / \mathrm{o}$ U-235, while that for the annular fuel was $3.0 \mathrm{w} / \mathrm{o}$ U-235. The fuel compacts contained a graphite matrix into which coated fuel particles were embedded. The fuel kernel was coated with pyrolytic carbon and silicon carbide. The fuel elements were grouped into fuel stringers containing about three long elements in the middle and one short element at each end. An aluminum support tube that passed through the center of the elements was used along with aluminum spacer plates to hold the stringer centrally in the fuel channel. The fuel stringers were loaded into the $7.5 \mathrm{~cm}$ diameter channels of 19-channel hexagonal graphite blocks that had a flat-to-flat distance of $40 \mathrm{~cm}$. [1]

The results of the HITREX experiments are contained in DRAGON project reports. A brief description of measurement parameters and techniques and a summary of the 
experimental results are contained in Ref. 1. These experiments are considered useful for LEU systems such as those considered for the block-type NGNP. The uranium enrichments (less than 4 w/o U-235) are lower than those considered in current NGNP designs. For this reason, HITREX-1 is ranked medium/high.

\section{Reference:}

1. V.E. Della-Loggia, T.S. Playle, "Reactor Physics Measurements on the Zero Energy HTR Lattice HITREX-1 at CEGB Berkeley Nuclear Laboratories,” D. P. Report 925, March 1975. (Obtained from CD containing OECD Dragon Project Reports, NEA1726/01.)

\subsection{HTLTR}

Based on a fuel cycle study showing that it was more attractive to use plutonium make-up in high-temperature gas-cooled reactors (HTGRs) than in LWRs, reactor physics experiments were performed in the high-temperature lattice test reactor (HTLTR) at the Battelle-Pacific Northwest Laboratory (BNWL) to obtain experimental data that could be used for evaluating computational methods and cross section data utilized for analyzing such plutonium-fueled systems. The HTLTR operated from 1968 to 1972.

A graphite fuel block served as the structural element for containing coated particle fuel. These blocks had dimensions of $9.4 \mathrm{~cm}$ x $9.4 \mathrm{~cm}$ x $61 \mathrm{~cm}$. Each block had 25 channels into which $\mathrm{PuO}_{2}$ coated particles or $\mathrm{ThO}_{2}$ particles and graphite particles were vibropacked. The $\mathrm{Pu}$ vector contained 73\% $\mathrm{Pu}-239,23 \% \mathrm{Pu}-240,3 \% \mathrm{Pu}-241$, and $1 \% \mathrm{Pu}-242$. The channels had a diameter of $1.27 \mathrm{~cm}$ and were on a pitch of $1.9 \mathrm{~cm}$. [1]

The HTGR test core was arranged in an $8 \times 8$ array in the central portion of the HTLTR. This zone was surrounded by $\mathrm{UO}_{2}$ shims, $5 \%$ enriched drivers, gadolinium shims, control rods, and fuel-poison columns. The HTLTR was electrically heated and could be operated for a long time with average temperatures up to $1000{ }^{\circ} \mathrm{C}$. [1]

Core parameters measured included core criticality, reaction rate traverses, material worths, and $\mathrm{k}_{\infty}$ variation with temperature.

The use of plutonium and thorium in the HTLTR experiments makes them of low priority to NGNP needs. However, these experiments might provide a useful database for the development of HTGRs initially fueled with plutonium.

\section{Reference:}

1. D. F. Newman, "Temperature-Dependent $\mathrm{k}_{\infty}$ for $\mathrm{a} \mathrm{ThO}_{2}-\mathrm{PuO}_{2} \mathrm{HTGR}$ Lattice," Nucl. Technol., 19, 66 (1973).

\subsection{HTTR}

The High Temperature Engineering Test Reactor (HTTR) of the Japan Atomic Energy Research Institute (JAERI) is a graphite-moderated and helium-gas-cooled reactor. The 
main objectives of the HTTR are to establish and upgrade the technological basis for advanced high-temperature gas-cooled reactors (HTGRs) and to conduct various irradiation tests for innovative high temperature basic research. The HTTR is designed for a thermal output of $30 \mathrm{MW}$ and an outlet temperature of $950{ }^{\circ} \mathrm{C}$. The first criticality of the HTTR was achieved on Nov.10, 1998, with an annular type core containing 19 fuel columns. The first full-power operation was achieved on 7 December 2001 with an average core outlet temperature of $850^{\circ} \mathrm{C}$, and operational licensing of the HTTR was approved on 6 March 2002. [1]

The reactor outlet coolant temperature at full power is set at either $850{ }^{\circ} \mathrm{C}$ or $950{ }^{\circ} \mathrm{C}$. The reactor operational mode at $850^{\circ} \mathrm{C}$ is defined as "rated operation," and the operational mode at $950{ }^{\circ} \mathrm{C}$ is "high temperature test operation" because operation of the HTTR is not allowed at $950{ }^{\circ} \mathrm{C}$ for the full life of the initial core. Tests such as the safety demonstration tests and irradiation tests are allowed only in the rated operation mode. The high-temperature nuclear process heat utilization system will be operated at the hightemperature test operational mode. [1]

The equivalent core diameter and effective core height of the HTTR are 230 and $290 \mathrm{~cm}$, respectively. The core consists of core components that are prismatic hexagonal blocks $58 \mathrm{~cm}$ in height and $36 \mathrm{~cm}$ in width across the flats. These include fuel assembly blocks, control rod guide blocks, replaceable reflector blocks, and irradiation blocks. The active core consists of 30 columns and seven control-rod guide columns. An additional nine control rod columns are arranged among the adjacent reflector graphite columns. Each fuel column consists of two top and two bottom reflector blocks and five fuel elements. [1] The active core is surrounded radially by graphite reflectors.

A fuel rod consists of a graphite sleeve containing 14 fuel compacts. The fuel rods are inserted into channels within the fuel graphite blocks. Each fuel compact contains about 13,000 coated fuel particles (CFPs) embedded in the graphite matrix. There are a total number of 12 different uranium enrichments. The highest and lowest enrichments are 9.9 and $3.4 \mathrm{w} / \mathrm{o}$, respectively. The higher-enrichment fuels are placed in the upper and outer core regions to reduce the maximum fuel temperature. Burnable poisons (BPs) made of boron carbide and carbon are inserted into two of three holes in the fuel graphite block. The coolant gas flow is downward through annular channels formed by the graphite block and the fuel rod. [1]

The initial critical loadings and reactor physics tests of the HTTR provide clean configurations against which analysis tools can be validated. Three different types of cores were created during fuel loading for start-up core physics experiments: thin and thick annular cores loaded with 18 and 24 fuel columns, respectively, and the fully loaded core with 30 fuel columns. These three core types have been proposed as benchmark problems within an IAEA Coordinated Research Project (CRP). [1] This indicates that based on geometrical considerations and core fuel and material constituents, the HTTR could be used for testing codes developed for annular and cylindrical core designs. Additionally, as the reactor is currently operating, there is the potential that pertinent and detailed configuration data can be obtained from JAERI as opposed to the situation for 
the DRAGON reactor that ended operation in the 1970s. For this reason, the HTTR data is considered of high interest for NGNP/VHTR development.

\section{Reference}

1. "Evaluation of High Temperature Gas Cooled Reactor Performance: Benchmark Analysis Related to the HTTR and HTR-10," IAEA TECDOC-1382, Vienna, 2003.

\subsection{MARIUS IV}

Reference 1 contains a brief description of the MARIUS IV critical experiments program that was planned by CEA (France) to provide data for validation of methods and data used in the analysis of the Gulf General Atomics (GGA) type lattice (thorium system). Prior to MARIUS IV, comprehensive experimental work on high temperature reactor (HTR) had been undertaken in the MARIUS assembly using clean low enriched hollowrod lattices. The earlier work included measurements of core criticality, bucklings, and reaction rates. Other measurements focused on temperature coefficients for fresh or plutonium-bearing fuels.

Planning for MARIUS IV required that the central part of the MARIUS assembly be replaced with GGA-type lattice. This zone was surrounded by another containing typical MARIUS fuel. The reference lattice is a $2.3 \mathrm{~cm}$ triangular-pitch graphite stack containing holes for fuel (1.57 cm diameter) or cooling ( $2.1 \mathrm{~cm}$ diameter). Each cooling hole was surrounded by 6 fuel holes. The lattice was fuelled with cylindrical graphite matrix compacts utilizing coated particles with a kernel containing either fertile $\mathrm{ThO}_{2}$ or a mixture of highly enriched $\mathrm{UO}_{2}(93 \mathrm{w} / \mathrm{o} \mathrm{U}-235)$ and $\mathrm{ThO}_{2}(\mathrm{Th} / \mathrm{U}$ ratio of 8$)$. The fueled region was to have a height of $1.4 \mathrm{~m}$.

Tests to obtain data on spectral indices, conversion ratio, and bucklings were planned for MARIUS IV. Measurements of control rod worths, flux distribution, reflector effects, and burnable poison effects were also planned.

Not much information was available to determine if this experiment was actually conducted. In any event, the use of the thorium fuel system makes the MARIUS IV experiments a low priority for NGNP purposes.

\section{Reference:}

1. M. Brunet, "Marius IV: A Critical Experiments Programme on GGA Type Lattices," DCPM 19/CEA-2 (obtained from OECD/NEA dataset on DRAGON Project Reports, from December 2003 IRhPE Meeting).

\subsection{PEACH BOTTOM HTGR}

The Peach Bottom reactor was the first experimental high-temperature gas-cooled power reactor built in the U.S. It had a power rating of $40 \mathrm{MWe}$ and operated from 1966 to 1974. The active core contained 804 closely packed cylindrical fuel elements that were relatively homogeneous mixtures of graphite, thorium, and highly enriched uranium (93 
w/o U-235). The core was surrounded on all sides by graphite reflector. While the fuel elements were homogeneous, the core was fairly heterogeneous, being composed of elements with different uranium and thorium loadings and different contents of burnable poison and rhodium to influence the moderator temperature coefficient. Control and emergency rods were also deployed in the core. The effective core diameter was $279 \mathrm{~cm}$ and the core height was $226 \mathrm{~cm}$.

The initial criticality of the Peach Bottom reactor in 1966 provided a good test of calculational methods for HTGR analysis. During the zero-power commissioning program of the Peach Bottom HTGR, the pulsed-source technique was used to obtain information on the reactivity of a large number of subcritical configurations of the reactor. The information was used to derive values of the reactor period and core reactivity states. These measured data were compared to calculated values. [1] According to References 1 and 2, other measurements included power distributions, control rod worths, and temperature coefficients.

Because Peach Bottom used highly enriched uranium and thorium fuel, it is considered a low-priority facility for benchmarking codes for uses related to the NGNP.

\section{References:}

1. C. A. Preskitt et al., "Interpretation of Pulsed-Source Experiments in the Peach Bottom HTGR,” Nucl. Sci. Eng., 29, 283 (1967).

2. "Critical Experiments and Reactor Physics Calculations for Low-Enriched High Temperature Gas-Cooled Reactors,” IAEA TECDOC-1249, Vienna, 2001.

\subsection{PEACH BOTTOM CRITICAL EXPERIMENTS}

In support of the development of the high-temperature gas-cooled reactor (HTGR) and its first prototype at Peach Bottom, General Atomics conducted critical experiments to provide confidence in the core calculational techniques and nuclear data used for HTGR analysis. [1] These experiments, called the Peach Bottom critical experiments, were performed from 1959 to 1962.

Two types of critical experiments were performed. The first was a test-lattice experiment in which measurements of reactions rates were examined in a lattice having a coldneutron spectrum typical of the HTGR. The project provided a method for verifying the resonance integral of thorium, the Doppler coefficient of thorium, the detailed flux distribution, and control rod effectiveness. The HTGR critical assembly was built in two halves. Overall reactivity control was achieved by separation of the two halves, and fine control was done using control rods. Most of the fuel elements consisted of rectangular graphite blocks containing fuel compacts in two parallel holes. The compacts contained graphite and either U-235 or thorium. For the test-lattice reactor the lattice cell region consisted of a hexagonal array of 19 HTGR fuel elements with the same material compositions and dimensions as those used in the actual Peach Bottom reactor. The testlattice cell had a diameter of $40.6 \mathrm{~cm}$. The reactivity measurements were made in the central fuel element. This test-cell region was surrounded by a buffer lattice region about 
$91.44 \mathrm{~cm}$ square consisting of critical-assembly fuel blocks containing U-235 and thorium. The composition of this buffer region was chosen to ensure that the reaction rates in this region were similar to that of the test region. The buffer region was surrounded by a $25.4 \mathrm{~cm}$ thick driver lattice containing graphite and U-235. This zone ensured that the entire assembly was critical. A $30.5 \mathrm{~cm}$ thick graphite reflector surrounded the driver zone. [1] The test-lattice reactor had a length of $182.9 \mathrm{~cm}$.

The second experiment focused on gross tests of the calculational procedures and data. A small critical assembly (approximately one-sixth the volume of the HTGR core) with a clean geometry and composition similar to that of the HTGR was constructed and surrounded on all sides by a $61 \mathrm{~cm}$ graphite reflector. The HTGR mock-up assembly had a core $152.4 \mathrm{~cm}$ in diameter and $121.9 \mathrm{~cm}$ in height, and it could be separated at the vertical mid-plane. This core was surrounded by a graphite reflector $61 \mathrm{~cm}$ thick. The core had 19 square holes for representing control rod positions and volume fractions in the actual Peach Bottom reactor. Rectangular fuel blocks containing U-235 and thorium were used in the assembly, with heavy metal isotopic ratios representative of the Peach Bottom reactor.

The Peach Bottom critical experiments were purposefully built for the validation of tools used for the analysis of highly enriched uranium- and thorium-fueled systems. While they provide good tests for such systems, they are not of direct use to NGNP-type systems that are designed to use low enriched uranium alone. Therefore, these experiments are rated low.

\section{Reference:}

1. R. G. Bardes et al., "High Temperature Gas Cooled Reactor Critical Experiment and Its Application," Proc. IAEA Symp. Exponential and Critical Experiments, Amsterdam, Netherlands, September 2-6, 1963, conference paper SM-42/37, International Atomic Energy Agency (1963).

\subsection{SHE}

The Semi-Homogeneous Experiment (SHE) was designed to investigate the reactor physics properties of low-enriched uranium (LEU), graphite-moderated cores. SHE used a horizontal split-table core design. The LEU enrichment was 20 w/o U-235. Each half of the split table was stacked with $\sim 400$ hollow tubes (inner zone) and $\sim 1,000$ solid graphite rods (outer zone), each $1.2 \mathrm{~m}$ long and $6.5 \mathrm{~cm}$ in outer diameter. The hollow tubes housed fuel rods containing fuel disks of $4.45 \mathrm{~cm}$ outer diameter, which were made of a homogeneous mixture of $20 \%$ enriched $\mathrm{UO}_{2}$ and pure graphite (graphite to $\mathrm{UO}_{2}$ ratio of 10:1). [1] JAERI used the SHE configuration from 1975 to 1985, but then converted it to the VHTRC configuration (see section 3.12). Homogeneous and heterogeneous cores, and cores simulating a very-high-temperature reactor (VHTR), were built during the SHE program. The primary distinctions between the SHE and VHTRC experiments are the fuel arrangements (rods versus block) and enrichments (2-6\% versus $20 \%)$. The conversion to the VHTRC experiments was deemed necessary in order to resolve some 
items specific to the VHTR design that could not be solved satisfactorily with the SHE configuration. [1]

The SHE program included measurements of critical masses, kinetic parameters, reactivity worths of control and burnable poison rods, reactivity temperature coefficients, and power distribution measurements.

In light of the differences between the fuel design of the SHE configuration and that of proposed NGNP, this experiment is being rated medium/high. However, it would be a useful addition to the set of cases evaluated for the NGNP as it employs a higher enrichment (20 w/o U-235) than those in the VHTRC experiments.

\section{Reference:}

1. Y. Kaneko, "Reactor Physics Research Activities Related to the Very High Temperature Reactor in Japan,” Nucl. Sci. Eng. 97, 145 (1987).

\subsection{UKAEA LOW ENRICHED HTR LATTICES (NESTOR/HECTOR)}

Because of concerns in Europe in the 1960s about the long-term supply of highly enriched uranium (HEU) and the lack of large-scale reprocessing facilities for thorium fuels, the interest in the DRAGON project shifted to the use of low enriched uranium as fuel for high temperature reactors (HTRs). Consequently, a series of reactor physics experiments was performed at AEE Winfrith on uniform arrays of HTR-type lattice cells using both $\mathrm{UO}_{2}$ and $\mathrm{PuO}_{2} / \mathrm{UO}_{2}$ fuels in coated particle form. The aims of the experiments were to (1) measure sets of cell reaction rates in the fast, resonance, and thermal regions for LEU fuel at cold and hot conditions, (2) determine material bucklings, and (3) determine reactivity coefficients. [1]

Two different facilities (the NESTOR and HECTOR reactors) were used for the physics experiments. The NESTOR reactor had a maximum power of $10 \mathrm{KW}$ and was used as a neutron source for measurements at ambient temperature. The NESTOR core had an annular geometry and used highly enriched uranium-aluminum alloy fuel plates cooled by light water and reflected by graphite. The reactor shielding was designed with five openings that allowed neutrons to be supplied to five caves that contained experimental assemblies. A Mark III gas-cooled reactor (GCR) subcritical assembly was built in one of the caves. This assembly (or stack) was $109 \mathrm{~cm}$ wide, $109 \mathrm{~cm}$ high, and $183 \mathrm{~cm}$ long, and contained 169 horizontally oriented fuel elements on a standard $8.34 \mathrm{~cm}$ square lattice pitch (a larger pitch of $11.8 \mathrm{~cm}$ was attainable by loading alternative channels). Experimental fuel elements were used in the central 5 x 5 array of channels; the remaining 144 channels used 3\% enriched oxide pellets or $3.5 \%$ enriched particulate fuels.

HECTOR is a zero-energy, graphite moderated and reflected reactor in which it was possible to have the central test region (CTR) heated by $\mathrm{CO}_{2}$ to about $430{ }^{\circ} \mathrm{C}$ while the remaining components were keep at room temperature. The particulate LEU fuel was used in the CTR along with aluminum-clad 3\% enriched $\mathrm{UO}_{2}$ pins (in cold CTR regions); 
the latter were used because the particulate fuel had to be shared by NESTOR and HECTOR. The HECTOR facility was used for the hot reaction rate and temperature coefficient measurements for the $\mathrm{UO}_{2}$ and $\mathrm{PuO}_{2} / \mathrm{UO}_{2}$ fuels.

Other exponential buckling measurements were performed in the projects. For these measurements, the NESTOR subcritical assembly was removed from the cave, dismantled and re-erected in another location. In these measurements, however, the central 5 x 5 array of the facility used the HECTOR fuel elements in order to allow direct comparison between the two sets of reaction rate measurements.

The particulate fuel used in the NESTOR and HECTOR measurements were vibrocompacted into graphite fuel cans to give a packing fraction of about $67 \%$. The fuel elements were formed by loading the fuel particles in the annular region formed between two concentric graphite sleeves that were $4 \mathrm{~cm}$ thick.

It is unclear if benchmark problems based on the NESTOR and HECTOR tests have been defined. Significant details on core description, experimental measurements and results (reaction rates, reactivity change with temperature, and bucklings), and references, are presented in Reference 1. These experiments appear to be useful to the validation of analysis methods for the LEU fuel being planned for the NGNP. The impact of the $\mathrm{CO}_{2}$ used for heating the central portion of HECTOR on the neutron spectrum needs to be assessed, however. The experiments are therefore ranked medium/high. The possibility of obtaining data from the U.K. nuclear authorities has to be evaluated.

Reference:

1. I. Johnstone, V.E. Della Loggia, "Experimental Results from the UKAEA Reactor Physics Programme on Low Enrichment HTR Lattices at AEE, Winfrith," D. P. Report 730, August 1970. (Obtained from CD containing OECD Dragon Project Reports, NEA1726/01.)

\subsection{VHTRC}

The VHTRC was a split-table, graphite-moderated critical assembly located at the Japan Atomic Energy Research Institute (JAERI). The assembly (core) consisted of two hexagonal-prism half assemblies. The hexagonal core was surrounded by a graphite reflector. Each half assembly was loaded with pin-in-block fuel of low enriched uranium in oxide form. Fuel rods were inserted in holes in the graphite blocks. The fuel compacts in a fuel rod were made of coated fuel particles (BISO) uniformly dispersed in the graphite matrix. The uranium enrichment of the fuel kernel ranged from 2 to $6 \mathrm{w} / \mathrm{o}$ U-235. The core height was $2.4 \mathrm{~m}$ and the hexagonal flat-to-flat dimension was $2.4 \mathrm{~m}$.

Benchmark problems have been defined for VHTRC configurations. In the experiments corresponding to the benchmark problems, the assembly was first brought to a critical state at room temperature. The assembly was then heated stepwise up to $200{ }^{\circ} \mathrm{C}$ by using electric heaters. At each step, the assembly temperature was kept constant so that an isothermal condition was realized, and subcritical reactivity was measured by the pulsed 
neutron method. At $200{ }^{\circ} \mathrm{C}$, criticality was again attained by fuel rod addition and control rod adjustment.

The VHTRC benchmark problem consisted of two parts: VH1-HP and VH1-HC. Case VH1-HP required the determination of the temperature coefficient of reactivity for five temperature steps between $20{ }^{\circ} \mathrm{C}$ and $200{ }^{\circ} \mathrm{C}$. On the other hand, $\mathrm{VH} 1-\mathrm{HC}$ required the determination of the effective multiplication factor for two temperature states at which the core was nearly critical. The requested items were the cell parameters, effective multiplication factor, temperature coefficient of reactivity, reaction rates, fission rate distributions and effective delayed neutron fraction. Complete descriptions of the problems are given in a published report. [1]

The experimental data from the VHTRC program have been rated high for block-type NGNP application.

\section{References:}

1. H. Yasuda, et al., "VHTRC Temperature Coefficient Benchmark Problem," JAERIData/Code 94-103, Japan Atomic Energy Research Institute, October 1994.

2. "Critical Experiments and Reactor Physics Calculations for Low-Enriched High Temperature Gas-Cooled Reactors," IAEA TECDOC 1249, Vienna, 2001. 


\subsection{Summary of Assessments}

Design and safety analysis calculations for the NGNP will require calculation of keffective, neutron flux distribution, and reaction cross sections, along with quantities that can be derived from flux and cross sections such as depletion, power distribution, etc. To confirm that analysis codes can predict these quantities with sufficient accuracy, the codes must be benchmarked against experimental measurements made in the closest possible conditions to those expected in the NGNP. Conditions relevant to benchmarking NGNP codes include geometry, fuel type, and, for a pebble-bed-type experimental facility, whether it achieved an asymptotic state. Code-calculated quantities to be compared with experimental data include k-effective, flux distributions (where measured values are available), and spectral indices (to determine whether the neutron energy spectra are comparable). Finally, the most important concern is whether the required data are available from an experimental facility.

Tables 2 and 3 compare the facilities discussed above with respect to various qualities desired for use in benchmarking computer codes. One of the column headings has different meanings in the two tables. A pebble-bed reactor operating at constant power for a sufficiently long time (on the order of two or three years) will approach asymptotic distributions of neutron flux and compositions. In principle, except to replace radiationdamaged reflector components, the pebble-bed reactor never needs to be shut down, so these asymptotic distributions will be approached more and more closely as time goes on. Prismatic-type reactors are batch-loaded, so the compositions change continuously with time. They do not approach asymptotic distributions as pebble-bed reactors do, and operation is interrupted at intervals of roughly two years for fuel removal, shuffling, and replacement. However, after several operating cycles, the distribution of compositions at cycle startup approaches an asymptotic configuration. The column heading "Asymptotic state or zero-power startup" refers to the true time-independent asymptotic configuration for pebble-bed reactors, but to the cycle-independent startup configuration for prismatictype reactors. 
Table 2. Comparison of Facilities Relevant to Codes for Modeling Pebble-Bed-Type Core.

\begin{tabular}{|c|c|c|c|c|c|c|}
\hline Facility & Geometry & Size & Fuel type & $\begin{array}{l}\text { Asymptotic } \\
\text { state or } \\
\text { zero-power } \\
\text { startup }\end{array}$ & $\begin{array}{l}\text { Availability } \\
\text { of data }\end{array}$ & Priority \\
\hline ASTRA & $\begin{array}{l}\text { Annular, but } \\
\text { not } \\
\text { azimuthally } \\
\text { symmetric }\end{array}$ & Small & As desired & $\begin{array}{l}\text { Zero-power } \\
\text { startup }\end{array}$ & $\begin{array}{l}\text { Existing } \\
\text { facility - } \\
\text { data can be } \\
\text { obtained }\end{array}$ & High \\
\hline AVR & Cylindrical & $\begin{array}{l}\text { Short; radial } \\
\text { extent } \\
\text { appropriate }\end{array}$ & $\begin{array}{l}\text { Various; some } \\
\text { low- } \\
\text { enrichment } \\
\text { TRISO }\end{array}$ & Both & Uncertain & High \\
\hline CESAR II & Hexagonal & Small & $\begin{array}{l}\text { Low-enriched } \\
\mathrm{UO}_{2}\end{array}$ & $\begin{array}{l}\text { Zero-power } \\
\text { startup }\end{array}$ & $\begin{array}{l}\text { Neutronics } \\
\text { data exist }\end{array}$ & Medium \\
\hline GROG & $\begin{array}{l}\text { Cylindrical or } \\
\text { annular }\end{array}$ & $\begin{array}{l}\text { Short; radial } \\
\text { extent } \\
\text { appropriate }\end{array}$ & $\begin{array}{l}\text { As desired, but } \\
\text { very low } \\
\text { packing } \\
\text { fraction }\end{array}$ & $\begin{array}{l}\text { Zero-power } \\
\text { startup }\end{array}$ & $\begin{array}{l}\text { Existing } \\
\text { facility - } \\
\text { data can be } \\
\text { obtained }\end{array}$ & Medium \\
\hline HTR-10 & Cylindrical & Small & $\begin{array}{l}\text { Low-enriched } \\
\text { TRISO }\end{array}$ & Both & $\begin{array}{l}\text { Existing } \\
\text { facility- data } \\
\text { can be } \\
\text { obtained }\end{array}$ & Highest \\
\hline $\begin{array}{l}\text { HTR- } \\
\text { PROTEUS }\end{array}$ & Cylindrical & Small & $\begin{array}{l}\text { LEU pebble- } \\
\text { bed fuel }\end{array}$ & Zero-power & $\begin{array}{l}\text { PSI and } \\
\text { IAEA would } \\
\text { need to be } \\
\text { contacted }\end{array}$ & High \\
\hline KAHTER & Cylindrical & Small & Uncertain & $\begin{array}{l}\text { Zero-power } \\
\text { startup }\end{array}$ & Uncertain & High \\
\hline SAR & Cylindrical & Small & $\begin{array}{l}\text { Probably low- } \\
\text { enrichment } \\
\text { TRISO }\end{array}$ & $\begin{array}{l}\text { Zero-power } \\
\text { startup }\end{array}$ & $\begin{array}{l}\text { Limited data } \\
\text { were } \\
\text { obtained for } \\
\text { this special- } \\
\text { purpose test }\end{array}$ & Low \\
\hline THTR & Cylindrical & Large & $\begin{array}{l}\text { Thorium- } \\
\text { uranium }\end{array}$ & $\begin{array}{l}\text { Most data for } \\
\text { zero power; } \\
\text { reactor } \\
\text { presumably } \\
\text { achieved } \\
\text { steady state }\end{array}$ & $\begin{array}{l}\text { More data } \\
\text { available for } \\
\text { zero-power } \\
\text { startup than } \\
\text { operating } \\
\text { conditions }\end{array}$ & Medium \\
\hline
\end{tabular}


Table 3. Comparison of Facilities Relevant to Codes for Modeling Prismatic Block Type Core.

\begin{tabular}{|c|c|c|c|c|c|c|}
\hline Facility & Geometry & Size & Fuel type & $\begin{array}{l}\text { Asymptotic } \\
\text { state or } \\
\text { zero-power } \\
\text { startup }\end{array}$ & $\begin{array}{l}\text { Availability } \\
\text { of data }\end{array}$ & Priority \\
\hline$\overline{\text { DRAGON }}$ & Hexagonal & Small & $\mathrm{HEU} / \mathrm{Th}$ & Both & $\begin{array}{l}\text { Data must be } \\
\text { retrieved } \\
\text { from } \\
\text { U.K./OECD }\end{array}$ & Low \\
\hline $\begin{array}{l}\text { Fort St. } \\
\text { Vrain }\end{array}$ & Cylindrical & Large & HEU/Th & Both & $\begin{array}{l}\text { Data is GA } \\
\text { proprietary }\end{array}$ & $\begin{array}{l}\text { Medium/ } \\
\text { High }\end{array}$ \\
\hline $\begin{array}{l}\text { GGA HTGR } \\
\text { criticals }\end{array}$ & Cylindrical & Small & $\mathrm{HEU}$ & Zero & $\begin{array}{l}\text { Data is GA } \\
\text { proprietary }\end{array}$ & $\begin{array}{l}\text { Medium/ } \\
\text { High }\end{array}$ \\
\hline HITREX-1 & Hexagonal & Small & LEU fuel & Zero & $\begin{array}{l}\text { U.K. nuclear } \\
\text { data }\end{array}$ & $\begin{array}{l}\text { Medium/ } \\
\text { High }\end{array}$ \\
\hline HTLTR & Block & Small & $\mathrm{Pu}-\mathrm{Th}$ fuel & Zero & PNNL data & Low \\
\hline HTTR & $\begin{array}{l}\text { Cylindrical/ } \\
\text { Annular }\end{array}$ & Small & LEU fuel & Both & $\begin{array}{l}\text { Existing } \\
\text { facility- data } \\
\text { can be } \\
\text { obtained }\end{array}$ & High \\
\hline MARIUS-IV & Unknown & Small & HEU-Th & Zero & Unknown & Low \\
\hline $\begin{array}{l}\text { Peach } \\
\text { Bottom } \\
\text { HTGR }\end{array}$ & Cylindrical & Small & HEU/Th & Both & $\begin{array}{l}\text { Data is GA } \\
\text { proprietary }\end{array}$ & Low \\
\hline $\begin{array}{l}\text { Peach } \\
\text { Bottom } \\
\text { Criticals }\end{array}$ & Cylindrical & Small & $\mathrm{LEU} / \mathrm{Th}$ & Zero & $\begin{array}{l}\text { Data is GA } \\
\text { proprietary }\end{array}$ & Low \\
\hline SHE & Hexagonal & Small & LEU fuel & Zero & JAERI data & $\begin{array}{l}\text { Medium/ } \\
\text { High }\end{array}$ \\
\hline $\begin{array}{l}\text { NESTOR/ } \\
\text { HECTOR }\end{array}$ & $\begin{array}{l}\text { Square and } \\
\text { cylindrical }\end{array}$ & Small & LEU fuel & $\begin{array}{l}\text { Zero and } \\
\text { elevated } \\
\text { temperatures }\end{array}$ & $\begin{array}{l}\text { U. K. nuclear } \\
\text { data }\end{array}$ & $\begin{array}{l}\text { Medium/ } \\
\text { High }\end{array}$ \\
\hline VHTRC & Hexagonal & Small & LEU fuel & Zero & JAERI data & High \\
\hline
\end{tabular}




\subsection{Conclusions}

A preliminary assessment of experimental data/facilities that could be used in the validation basis of data and tools for design and analysis of the NGNP has been completed. It was found that various experiments have been performed internationally since the early 1960s to confirm data and validate the design tools used for HTGR designs. Many of the operational and experimental data on HTGR reactor physics have been obtained through previous high-temperature reactor operations such as DRAGON, AVR, Peach Bottom, Fort Saint Vrain, and THTR. Others have been obtained in experimental facilities devoted to investigating different (and sometimes specific) reactor physics issues. In addition, other valuable experimental data have been added through recent national or international experimental activities.

Trends were observed in the experiments that were performed in the various facilities investigated. It was found that most of the experiments for block-type cores were performed in the U.S., while those on pebble-bed cores were done predominantly in Europe. Most of the early U.S. experiments used highly enriched uranium. This was not typically the case for the European experiments. Additionally, experiments are currently being performed for both pebble-bed and block type cores in Asia (Japan and China).

The HTGR cores have evolved to improve system economy and safety. The NGNP core concept, one of the most advanced, has many different technical aspects compared to those of the early HTGRs. The evolution of the core limits the applicability and usefulness of the existing experimental data to NGNP core designs. Additionally, in the case of the data produced on national or commercial bases, the availability of those data might be quite limited.

This preliminary assessment revealed that four experimental data and facilities have the highest priority for pebble-bed type cores. These are the HTR-PROTEUS, HTR-10, ASTRA, and AVR. In terms of data applicability and availability, the HTTR and VHTRC data were rated highly as being directly pertinent to the evaluation of the pedigree of data and tools used for the design and analysis of block-type NGNP cores. 
Appendix A

ASSESSMENT OF EXPERIMENTS FOR PEBBLE-BED REACTOR PHYSICS CODE BENCHMARKING 


\section{APPENDIX A.1}

\section{ASSESSMENT OF ASTRA}

- Purpose of the experiment

o Evaluate 13 critical thermal pebble-bed graphite configurations containing $\mathrm{UO}_{2}$ fuel particles

- Description of facility and experimental configurations

o Core geometry: cylindrical, annular, and square, in an octagonal cavity; core diameter $($ or side $)=93.8-181 \mathrm{~cm}$, core height $=176-380 \mathrm{~cm}$

o Fuel geometry: spherical pebbles with inner fuel-bearing zone and outer pure graphite shell

o Core materials

- Fuel type: spherical $\mathrm{UO}_{2}$ kernels, enrichment $21 \%$, heavy metal content per pebble TBD

- Cladding or coating: TRISO particle configuration (porous carbon buffer, inner pyrolytic carbon layer, SiC layer, outer pyrolytic carbon layer)

- Moderator: graphite matrix in which TRISO particles are embedded

- Core comprises several zones, including fuel zone and (for annular cases) mixing zone and inner reflector zone (with graphite pebbles); some absorber pebbles with boron are present in all zones

- Coolant: N/A

- Conditions

o Temperature: ambient

o Power: 0

- Physical parameters measured

o Critical core height

o Control rod worths and their dependence on location of the rods

o Reactivity effects of various experimental samples, including fuel pebbles, graphite pebbles, and absorber pebbles

o Reactivity coefficients such as $\partial \rho / \partial H$ (where $\rho=$ reactivity and $H=$ core height)

o Kinetic parameters such as decay constant and prompt neutron lifetime

o Reaction rate distributions and their dependence on changes in the annular core configuration (measured by detectors)

- Experimental uncertainties provided? Not presently, but they will be provided when the evaluation is completed. 
- Source of experimental data: Dr. Evgeny Glushkov of the Russian Research Center (Kurchatov Institute).

- Has a benchmark problem been developed from experimental data? Yes.

- Applicability of data to V\&V of methods for the NGNP

o Data have been used in comparison with MCNP model of fresh core

o Data can be used in comparison with VSOP models of fresh core

o Data can be used in comparison with PEBBED models of fresh core

o Characterization of spectral indices: TBD

o Advanced sensitivity analysis: TBD

o Octagonal cavity makes modeling by PEBBED difficult, less faithful to actual configuration.

- Prioritization of cases: TBD.

- Priority of experiment relative to others: High, because needed data can still be obtained. A problem (for pebble-bed cores) may be presented by the octagonal cavity. 


\section{APPENDIX A.2}

\section{ASSESSMENT OF AVR}

- Purposes (original and added) of the experiment

0 To verify the principle of the pebble-bed reactor (PBR)

o To demonstrate successful operation of a PBR

o To provide a test bed for fuel elements

o To verify and demonstrate the inherent safety features of the PBR

o To demonstrate operation with high coolant outlet temperature $\left(950^{\circ} \mathrm{C}\right)$.

- Description of facility and experimental configurations

o Core geometry: cylindrical; core diameter $=300 \mathrm{~cm}$, core height $=280 \mathrm{~cm}$

o Fuel geometry: spherical pebbles with inner fuel-bearing zone and outer pure graphite shell

o Core materials (Note: other fuel designs were used in early part of operating period, including BISO microspheres and uranium/thorium carbide fuel kernels)

- Fuel type: spherical $\mathrm{UO}_{2} / \mathrm{ThO}_{2}$ kernels with $93 \%, 16.7 \%$, and10\% enriched U, $1 \mathrm{~g} \mathrm{U}-235$ per fuel pebble, and Th mass per fuel pebble 10,5 , and $0 \mathrm{~g}$ for the different $\mathrm{U}$ enrichments, respectively

- Cladding or coating: TRISO particle configuration (porous carbon buffer, inner pyrolytic carbon layer, SiC layer, outer pyrolytic carbon layer)

- Moderator: graphite matrix in which TRISO particles are embedded

- Coolant: helium

- Conditions

o For operation at power:

- Temperature: $275^{\circ} \mathrm{C}$ at reactor inlet, $950{ }^{\circ} \mathrm{C}$ at reactor outlet (in final configuration)

- Primary helium pressure: $10.8 \mathrm{bar}=1.08 \mathrm{Mpa}$

- Power: $46 \mathrm{MWt}, 15 \mathrm{MWe}$

- Helium mass flow rate at full power: $13 \mathrm{~kg} / \mathrm{s}$

- Physical parameters measured

o A large number of experiments have been performed in the AVR, including steady-state and dynamic reactor physics measurements and determination of temperature coefficients of reactivity. These experiments are listed in the reference cited below, but the detailed reports on the experiments will have to be obtained from Jülich.

- Experimental uncertainties provided? Not presently, but they are presumably contained in the reports we will request from Jülich. 
- Source of information used for this assessment: AVR - Experimental HighTemperature Reactor: 21 Years of Successful Operation for a Future Energy Technology, Association of German Engineers (VDI) - The Society for Energy Technologies (Publ.), VDI Verlag GmbH, Düsseldorf, 1990.

- Has a benchmark problem been developed from experimental data? No.

- Applicability of data to V\&V of methods for the NGNP:

o Data should be applicable to modeling by MCNP

o Data should be applicable to modeling by VSOP

o Data should be applicable to modeling by PEBBED

o Characterization of spectral indices: TBD

o Advanced sensitivity analysis: TBD

0 The biggest uncertainty is the question of what data are actually available.

- Prioritization of cases: TBD

- Priority of overall experiment relative to others: High (for pebble-bed cores). 


\section{APPENDIX A.3}

\section{ASSESSMENT OF CESAR II}

- Purpose of the experiment

o To determine detailed neutron flux for pebble-bed reactors

o To provide a test bed for fuel elements

- Description of facility and experimental configurations

o Core geometry: hexagonal; active pebble-bed core diameter $=75 \mathrm{~cm}$, core height $=2 \mathrm{~m}$

o Fuel geometry: $6 \mathrm{~cm}$ spheres

o Core materials

- Fuel type: $\mathrm{UO}_{2}$ kernels, $3.5 \%$ enriched

- Cladding or coating: HTR-type fuel pebbles, presumably TRISO particle configuration (porous carbon buffer, inner pyrolytic carbon layer, $\mathrm{SiC}$ layer, outer pyrolytic carbon layer)

- Moderator: graphite matrix in which the fuel particles are embedded

- Conditions

o Temperature: ambient

o Power: zero power

- Physical parameters measured

o Radial neutron flux for the mid-plane of the core; 4 energy groups

o Neutron flux in the transition zones between central core and reflector

o Conversion ratio

o Reaction rates and spectral indices

o Control rod worths

o Pu effects

- Experimental uncertainties provided? Unknown

- Pedigree of experimental data: Unknown

- Source of experimental data:

o G. Langlet et al., "Results of CESAR II Critical Facility with Low Enriched Fuel Balls," DCPM 15/CEA-KFA 1, June 1972. (Obtained from OECD/NEA dataset on DRAGON Project Reports, from December 2003 IRhPE Meeting.)

o G. Langlet et al., "Results of Pebble Bed Experiments in CESAR," DCPM 17/CEA-KFA 1, October 1973. (Obtained from OECD/NEA dataset on DRAGON Project Reports, from December 2003 IRhPE Meeting.)

- Has a benchmark problem been developed from experimental data? Yes.

- Applicability of data to V\&V of methods for the NGNP 
o Data have been used in comparison with APOLLO and ALCYON 2D codes

o Data can be used in comparison with MCNP models of fresh core

o Data can be used in comparison with PEBBED models of fresh core

o Characterization of spectral indices: TBD

o Advanced sensitivity analysis: TBD

- Prioritization of cases: TBD 


\section{APPENDIX A.4}

\section{ASSESSMENT OF GROG}

- Purpose of the experiment

o Evaluate 16 critical assembly configurations

- Intended to study the physics of various uranium-graphite reactors by virtue of an easily configurable geometry

- Description of facility and experimental configurations

o Core geometry: cubic, with cylindrical UFE fuel elements and spherical fuel elements; core size ( side length) $=75.0-100 \mathrm{~cm}$, core height $=92.0$ $124.0 \mathrm{~cm}$

o Core geometry: cylindrical with spherical fuel elements; core size $=320.0$ $\mathrm{cm}$ diameter, 62.5-83.3 $\mathrm{cm}$ height

o Fuel geometry: $50 \mathrm{~mm}$ diameter cylindrical universal fuel elements (UFE) with homogeneous mixture of $\mathrm{CF}_{2}$ and $\mathrm{UO}_{2}$ of 10,25 , and $50 \mathrm{~mm}$ in height; spherical $\mathrm{UO}_{2}$

o Core materials

- Fuel type: Cylindrical UFE and spherical $\mathrm{UO}_{2}$ kernels, enrichment $10 \%$ in both cases, cylindrical geometry tests used $6 \%$ enriched $\mathrm{UO}_{2}$

- Cladding or coating: unknown at this time

- Moderator: graphite matrix in which the fuel elements are placed in channels by removal of graphite

- Many different critical core geometries have been evaluated, including various stackings of fuel, moderator, and reflectors

- Coolant: N/A

- Conditions

o Temperature: ambient

o Power: 0

- Physical parameters measured

o Critical parameters

o Control rod worth

o Reactivity effects of various parameters, including fuel geometry, core geometry pebbles, and absorber material (boronated paper discs)

o Special characteristics

o Distribution of reaction rates in a critical assembly, including microdistributions in fuel elements

o Spatial-temporal effects on perturbation introductions

- Experimental uncertainties provided? Not presently, but they will be provided when the evaluation is completed. 
- Source of experimental data: Dr. Evgeny Glushkov of the Russian Research Center (Kurchatov Institute).

- Has a benchmark problem been developed from experimental data? Yes.

- Applicability of data to V\&V of methods for the NGNP

o Data can be used in comparison with MCNP model of fresh core

o Data can be used in comparison with VSOP models of fresh core

o Data can be used in comparison with PEBBED models of fresh core

o Characterization of spectral indices: TBD

o Advanced sensitivity analysis: TBD

- Prioritization of cases: TBD

- Priority of experiment relative to others: Medium (for pebble-bed cores) 


\section{APPENDIX A.5}

\section{ASSESSMENT OF HTR-10}

- Purpose of the experiment

o To acquire experience and capability in PBR design, construction, and operation

o To provide a test bed for fuel elements

0 To verify and demonstrate the inherent safety features of the modular HTGR

o To demonstrate co-generation and the gas/steam combined cycle

o To develop high-temperature process heat utilization.

- Description of facility and experimental configurations

o Core geometry: cylindrical; core diameter $=180 \mathrm{~cm}$, core height $=197 \mathrm{~cm}$

o Fuel geometry: spherical pebbles with inner fuel-bearing zone and outer pure graphite shell

o Core materials

- Fuel type: spherical $\mathrm{UO}_{2}$ kernels, $17 \%$ enriched, $5 \mathrm{~g}$ heavy metal per fuel pebble

- Cladding or coating: TRISO particle configuration (porous carbon buffer, inner pyrolytic carbon layer, $\mathrm{SiC}$ layer, outer pyrolytic carbon layer)

- Moderator: graphite matrix in which TRISO particles are embedded

- Coolant: helium

- Conditions

o For initial criticality: zero power, stagnant air in void space, and ambient temperature

o For operation at power:

- Temperature: $250{ }^{\circ} \mathrm{C}$ at reactor inlet, $700^{\circ} \mathrm{C}$ at reactor outlet

- Primary helium pressure: $3.0 \mathrm{Mpa}$

- Power: $10 \mathrm{MWt}$

- Helium mass flow rate at full power: $4.3 \mathrm{~kg} / \mathrm{s}$

- Physical parameters measured

o Number of fuel pebbles plus pure graphite pebbles (at a ratio of 57:43) for initial criticality

o Future R\&D activities:

- Performance verification of various systems and components

- Safety demonstration experiments/tests

- Experimental uncertainties provided? Not presently, but they will be provided by the Chinese for ICSBEP. 
- Source of experimental data: Professor Yuliang Sun, Institute of Nuclear and New Energy Technology (INET), Tsinghua University.

- Has a benchmark problem been developed from experimental data? Yes.

- Applicability of data to V\&V of methods for the NGNP

o Data have been used in comparison with VSOP model of fresh core

o Data can be used in comparison with MCNP models of fresh core

o Data can be used in comparison with PEBBED models of fresh core

0 If proper measurements are made, data can be used in comparison with VSOP and PEBBED models of equilibrium core

o Characterization of spectral indices: TBD

o Advanced sensitivity analysis: TBD

- Prioritization of cases: TBD

- Priority of experiment relative to others: Highest (for pebble-bed cores) 


\section{APPENDIX A.6}

\section{ASSESSMENT OF HTR-PROTEUS}

- Purpose of the reactor

o Fill gaps in validation data for physics methods used for core design of gas-cooled reactors fueled with low enriched uranium (LEU); ten different configurations were evaluated under the HTR-PROTEUS project (some of these had variants)

- Description of facility and experimental configurations

0 Core geometry: cylindrical core; core (equivalent) diameter $=1.25 \mathrm{~m}$, core height $=0.843 \mathrm{~m}$ to $1.73 \mathrm{~m}$ (with simulated water ingress, smaller core heights were utilized); core H/D from 0.7 to 1.4

o Fuel geometry: spherical pebbles with inner fuel-bearing zone and outer pure graphite shell

o Core materials

- Fuel type: LEU pebble-type fuel with enrichment of 16.8 w/o U-235

- Cladding or coating: TRISO particle configuration (porous carbon buffer, inner pyrolytic carbon layer, $\mathrm{SiC}$ layer, outer pyrolytic carbon layer)

- Moderator: graphite matrix in which TRISO particles are embedded

- Coolant: air

- Conditions

o Power: Zero power

- Temperature: room temperature

- Physical parameters measured

o Core Criticality

o Flux distribution measurements and spectral distribution measurements (including measurements in side reflector)

o Kinetic parameter measurements

o Worth of in-core and reflector control rods (partly and fully inserted)

o Reactivity worths of samples

o Reaction rate profiles

0 Effects of moisture ingress over range of water density up to $0.25 \mathrm{gm}$ $\mathrm{H}_{2} \mathrm{O} / \mathrm{cm}^{3}$ void (corresponds to $0.065 \mathrm{gm} \mathrm{H}_{2} \mathrm{O} / \mathrm{cm}^{3}$ core for PROTEUS); Water is simulated with polyethylene inserts; the effects on core reactivity, control rod and burnable poison worths, prompt neutron lifetime, and flux and power distributions were investigated

- Experimental uncertainties available? Yes. Some of these data are provided in the IAEA TECDOC 1249, IAEA 2001. 
- Source of information used for this assessment

o "Critical Experiments and Reactor Physics Calculations for Low-Enriched High Temperature Gas-Cooled Reactors," IAEA TECDOC 1249, Vienna, 2001

o O. P. Joneja and Y. Xu, "Monte Carlo Simulation of HTR-PROTEUS and Comparison with Measurements," PSI Technical Memorandum, TM-4196-23, August 1996

o Information on facility and experimental configurations are contained in PSI internal documents and IAEA TECDOC 1249

- Has a benchmark problem been developed from experimental data?

o Lattice and whole-core calculational benchmarks were defined within the CRP. Parameters to be calculated include lattice and core multiplication factors, critical height, neutron balance, lattice and core spectral indices, and temperature coefficients (the latter mocking up heating experiments conducted by JAERI on pin-in-block-type critical assembly, VHTRC); both unit-cell parameters and whole-core criticality and temperature coefficients are reported as function of temperature (the latter are compared to experimental results)

o Calculated and experimental data have been compared in PSI studies; such comparisons have also been done by other international institutions; some of these might form basis for reactor physics benchmarks; IAEA TECDOC 1249 provides some information on the experiments and calculation-to-experiment ratios for various core parameters

- Applicability of data to V\&V of methods for the NGNP: The HTR-PROTEUS data are expected to be useful to the validation and verification of design methods for the pebble-bed NGNP

- Prioritization of cases: All configurations are highly relevant to pebble-bed NGNP applications

- Priority of experiment relative to others: Rated high for pebble-bed cores 


\section{APPENDIX A.7}

\section{ASSESSMENT OF KAHTER}

- Purpose of the reactor

o To perform critical experiments for pebble-bed reactors

- Description of facility and experimental configurations

o Core geometry: cylindrical; core diameter $=216 \mathrm{~cm}$, core height $\leq 276 \mathrm{~cm}$

o Fuel geometry: spherical pebbles with inner fuel-bearing zone and outer pure graphite shell

o Core materials

- Fuel type: spherical $\mathrm{UO}_{2} / \mathrm{ThO}_{2}$ or $\mathrm{UC} / \mathrm{ThC}$ kernels as appropriate for reactor being simulated

- Cladding or coating: TRISO particle configuration (porous carbon buffer, inner pyrolytic carbon layer, $\mathrm{SiC}$ layer, outer pyrolytic carbon layer)

- Moderator: graphite matrix in which TRISO particles are embedded; also, pure graphite balls and absorber balls with boron and hafnium

- Coolant: N/A

- Conditions

o For zero-power core physics tests:

- Temperature: ambient

- Interstitial gas pressure: 1 bar

- Power: zero

- Interstitial gas mass flow rate: zero

- Physical parameters measured

o Critical mass, reactivity, neutron flux, k-effective, reaction rates

- Experimental uncertainties provided? Not in literature seen to date.

- Source of information used for this assessment:

o V. Drüke and D. Filges, "The Critical HTGR Test Facility KAHTER - An Experimental Program for Verification of Theoretical Models, Codes, and Nuclear Data Bases," Nucl. Sci. Eng. 97, 30-36 (1987)

o V Drüke, D. Filges, R. D. Neef, N. Paul, and H. Schaal, "Experiments on Inhomogeneous Fuel Loading at the Critical HTGR Test Facility KAHTER: A Study for the Future Loading Concept of Pebble-Bed Reactors," Nucl. Sci. Eng. 97, 37-52 (1987).

- Has a benchmark problem been developed from experimental data? The critical experiment was built for the purpose of benchmarking codes. There are several problems that could be repeated with MCNP and PEBBED. 
- Applicability of data to V\&V of methods for the NGNP: Moderate. The KAHTER facility was used to represent AVR and THTR, so the conditions do not fully represent those in the NGNP.

o Data can be used in comparison with MCNP model of fresh core

o Data can be used in comparison with VSOP models of fresh core

o Data can be used in comparison with PEBBED models of fresh core

o Characterization of spectral indices: TBD

o Advanced sensitivity analysis: TBD

- Prioritization of cases: TBD

- Priority of experiment relative to others: High (for pebble-bed cores) 


\section{APPENDIX A.8}

\section{ASSESSMENT OF SAR}

- Note: SAR is the Siemens-Argonaut Reactor at the Technische Universität Graz, Austria

- Purpose of the reactor

0 This is a research reactor at a university. It was modified to perform tests of the reactivity insertions caused by water ingress into a pebble-bed core.

- Description of facility and experimental configurations

o Core geometry:

This reactor is normally configured as an annular core with inner and outer graphite reflectors. The fuel is in a set of aluminum plate fuel elements much like those in the ATR, except that the plates are not curved. The individual elements are separated by wedge-shaped graphite spacers to accommodate the change in angle in the elements from one azimuthal location to the next. In the water-ingress experiments, the inner reflector was replaced by 1130 fuel spheres of the AVR type. The region where the pebbles were placed is approximately $50 \mathrm{~cm}$ in diameter and $80 \mathrm{~cm}$ high.

o Fuel geometry in test region: spherical pebbles with inner fuel-bearing zone and outer pure graphite shell

o Core materials

- Fuel type: spherical UC/ThC kernels

- Cladding or coating: TRISO particle configuration (porous carbon buffer, inner pyrolytic carbon layer, SiC layer, outer pyrolytic carbon layer)

- Moderator: graphite matrix in which TRISO particles are embedded; also, pure graphite balls and absorber balls with boron and hafnium

- Coolant: N/A

- The interstitial regions in the pebble bed were filled to a gradually increasing depth with polyethylene and polystyrol granules to represent water by their hydrogen content

- Conditions

o For zero-power core physics tests:

- Temperature: ambient

- Interstitial gas pressure: 1 bar

- Power: zero

- Interstitial gas mass flow rate: zero

- Physical parameters measured

o Reaction rates, k-effective, reactivity, neutron flux profiles in seven energy groups 
- Experimental uncertainties provided? Not in literature seen to date.

- Source of information used for this assessment:

o $\quad$ F. Schürrer, W. Ninaus, K. Oswald, R. Rabitsch, Hj. Müller, and R.D. Neef, "Steady-State Neutronic Investigations to the Accident of Water Ingress in Systems with Pebble-Bed High-Temperature Gas-Cooled Fuel," Nucl. Sci. Eng. 97, 72-88 (1987).

- Has a benchmark problem been developed from experimental data? The experiment was built for the purpose of benchmarking codes. The calculations could be repeated with MCNP, VSOP, and PEBBED.

- Applicability of data to V\&V of methods for the NGNP: Low. The SAR facility was used to represent AVR, so the conditions do not fully represent those in the NGNP. Furthermore, the geometry of the annular driver core is a complication that would obscure the calculations in terms of their application to the NGNP. However, this experiment would check the ability of our codes to predict the reactivity insertion caused by water ingress.

- Prioritization of cases: TBD

- Priority of experiment relative to others: Low (for pebble-bed cores). 


\section{APPENDIX A.9}

\section{ASSESSMENT OF THTR}

- Purpose of the reactor

o To generate electric power.

- Description of facility and experimental configurations

o Core geometry: cylindrical; core diameter $=560 \mathrm{~cm}$, core height $=600 \mathrm{~cm}$

o Fuel geometry: spherical pebbles with inner fuel-bearing zone and outer pure graphite shell

o Core materials

- Fuel type: spherical $\mathrm{UO}_{2} / \mathrm{ThO}_{2}$ or $\mathrm{UC} / \mathrm{ThC}$ kernels with fully enriched $U$ and 10 times as much Th-232

- Cladding or coating: TRISO particle configuration (porous carbon buffer, inner pyrolytic carbon layer, $\mathrm{SiC}$ layer, outer pyrolytic carbon layer)

- Moderator: graphite matrix in which TRISO particles are embedded; also, pure graphite balls and absorber balls with boron and hafnium

- Coolant: helium (nitrogen for zero-power startup tests)

- Conditions

o For operation at power:

- Temperature: $250{ }^{\circ} \mathrm{C}$ at reactor inlet, $750{ }^{\circ} \mathrm{C}$ at reactor outlet

- Primary helium pressure: Unknown

- Power: $760 \mathrm{MWt}, 307 \mathrm{MWe}$

- Helium mass flow rate at full power: Unknown

o For zero-power core physics tests:

- Temperature: $70{ }^{\circ} \mathrm{C}-210^{\circ} \mathrm{C}$

- Primary nitrogen pressure: 1 bar - 15 bar

- Power: zero

- Nitrogen mass flow rate: zero

- Physical parameters measured

o Count rate as a function of pebbles loaded (in initial approach to criticality), reactivity versus time during insertion of reflector rods, temperature coefficients of reactivity

- Experimental uncertainties provided? Yes.

- Source of information used for this assessment:

o http://mail.ada.com.tr/ hkose/me428/\# Toc452796909

o G. Dietrich \& N. Roehl, "Decommissioning of the thorium hightemperature reactor, THTR 300," Trans. ANS 포, 31 Dec 96 
o S. Brandes, H. Daoud, and U. Schmid, "Core Physics Tests of Thorium High-Temperature Reactor Pebble-Bed Core at Zero Power," Nucl. Sci. Eng. 97, 89-95 (1987)

- Has a benchmark problem been developed from experimental data? No.

- Applicability of data to V\&V of methods for the NGNP: TBD. It is unclear whether useful data can be obtained for THTR.

- Prioritization of cases: TBD

- Priority of experiment relative to others: TBD; probably medium (for pebble-bed cores). 
Appendix B

ASSESSMENT OF EXPERIMENTS FOR PRISMATIC-BLOCK-TYPE REACTOR PHYSICS CODE BENCHMARKING 


\section{APPENDIX B.1}

\section{ASSESSMENT OF DRAGON}

- Purpose of the reactor

o Experimental and material testing reactor

- Description of facility and experimental configurations

o Core geometry: hexagonal; active core diameter $=1.1 \mathrm{~m}$, active core height $=1.6 \mathrm{~m}$

o Fuel geometry: Fuel elements typically containing seven rods (channels)

o Core materials

- Fuel type: A diverse set of fuel elements was employed in the program, mostly highly enriched uranium-thorium carbide fuel and low enriched uranium-oxide fuel; highly enriched $\mathrm{UO}_{2}$ driver fuel was also used

- Cladding or coating: TRISO particle configuration (porous carbon layer, inner pyrocarbon layer, $\mathrm{SiC}$ layer, outer pyrolytic carbon layer)

- Moderator: graphite matrix in which TRISO particles are embedded

- Coolant: helium

- Conditions

o For operation at power:

- Temperature: $350{ }^{\circ} \mathrm{C}$ at reactor inlet, $750{ }^{\circ} \mathrm{C}$ at reactor outlet

- Primary helium pressure: 20 bar

- Power: $20 \mathrm{MWt}$

- Helium mass flow rate at full power: $9.6 \mathrm{~kg} / \mathrm{s}$

o For zero-power core physics tests:

- Power: zero

- Physical parameters measured: Measurements were performed at the beginning of the first core and other reload cores. The useful measurements are typically those done for the fresh core, in order to eliminate uncertainties in the calculation of burned fuel. Measurements included

o Excess reactivity and rod worths in cold and hot conditions at the beginning and end of core lives

o Temperature coefficients and defects (isothermal temperature coefficients) between $50-120{ }^{\circ} \mathrm{C}$

$0 \quad \mathrm{U}-235$ and $\mathrm{Pu} / \mathrm{U}$ fission rates, fast fission rates, and relative conversion ratios at zero power prior to charge IV of the reactor

o Investigation of reactivity effect of water ingress (by insertion of hydrogenous material in fuel element)

o Transient tests (reactor response to changes in plant conditions), and graphite damage rate tests 
- Experimental uncertainties provided? Yes.

- Source of information used for this assessment:

0 R.A. Simon and P.D. Capp, "Operating Experience with the DRAGON High Temperature Reactor Experiment," HTR-2002, Proceedings of the Conference on High Temperature Reactors, Petten, NL, April 22-24, 2002, Reproduced by the IAEA Vienna, Austria, 2002.

o J. P. H. Blake, V.E. Della Loggia, J. Reber, "Physics Experiments on the Dragon Reactor Experiment," D. P. Report 166, May 1963. (Obtained from CD containing OECD Dragon Project Reports, NEA-1726/01.)

o I. R. Cameron et al., "Measurements of Control Rod Worth and Excess Reactivity on the First Core of Dragon", D. P. Report 359, July 1965. (Obtained from CD containing OECD Dragon Project Reports, NEA1726/01.)

o E. Smith, "DRAGON Plant Record - The DRAGON Core," D. P. Report 507, May 1965. (Obtained from CD containing OECD Dragon Project Reports, NEA-1726/01.)

o V. E. Della Loggia et al., "Zero Energy Experiments on the Dragon Reactor Prior to Charge IV Startup”, D. P. Report 820, Jan. 1973. (Obtained from CD containing OECD Dragon Project Reports, NEA1726/01.)

o G. R. Cullington and D. C. King, "Physics Experiments with the Operating Reactor," DCPM 17/DRAGON 3, September 1973. (Obtained from OECD/NEA dataset on DRAGON Project Reports, from December 2003 IRhPE Meeting.)

o M. Lancefield and F. Woloch, "A WIMS Analysis of the Zero Energy Experiments Performed on the DRAGON Reactor: First Results," D. P. Report 904, November 1974. (Obtained from CD containing OECD Dragon Project Reports, NEA-1726/01.)

o F. P. O. Ashworth et al., "A Summary \& Evaluation of the Achievements of the DRAGON Project \& its Contribution to the Development of the High Temperature Reactor (HTR),” D. P. Report 1000, November 1978. (Obtained from CD containing Dragon Project Reports, NEA-1726/01.)

- Has a benchmark problem been developed from experimental data? No; however, comparisons of calculation to measurement data were found in literature

- Applicability of data to V\&V of methods for the NGNP: TBD. It is unclear whether useful data can be obtained for the DRAGON project. The DRAGON facility was used to represent previous HTR designs of the block type, so the conditions do not fully represent those in the NGNP

- Prioritization of cases: TBD

Priority of experiment relative to others: probably medium (for block-type cores) 


\section{APPENDIX B.2}

\section{ASSESSMENT OF FORT ST. VRAIN}

- Purposes of the experiments

o To confirm the adequacy of the calculational models used in the core design

o To demonstrate successful operation of a graphite-moderated HTGR

o To test performance of graphite-moderated HTGR

- Description of facility and experimental configurations

o Core geometry: right circular cylinder; core diameter $=590 \mathrm{~cm}$, core height $=480 \mathrm{~cm}$

o Fuel geometry: hexagonal fuel elements of pin-in-block type; six individual fuel elements are stacked vertically in columns; each fuel element is $386 \mathrm{~mm}$ wide across the hexagonal flat and $792 \mathrm{~mm}$ in length

o Core materials

- Fuel type: blended beds of coated fuel particles and coke filler; the fresh fuel consists of highly enriched (93\% U-235) uranium and fertile thorium at a respective weight ratio of $1 / 10$

- Cladding or coating: individual particles are coated with layers of pyrolytic carbon and $\mathrm{SiC}$, bonded into the compact fuel elements

- Moderator: graphite matrix in which fuel particles are embedded

- Outer reflector of graphite with an effective thickness of 1.0-1.2 m in roughly the same size and shape as hexagonal fuel rods; an outer reflector of permanent graphite blocks surrounds the core

- Coolant: helium

- Conditions

o For operation at power:

- Temperature: $400{ }^{\circ} \mathrm{C}$ at reactor inlet, $775^{\circ} \mathrm{C}$ at reactor outlet; isothermal temperature condition evaluated as average between inlet and outlet temperatures in $28^{\circ} \mathrm{C}$ intervals ranging between ambient to $148^{\circ} \mathrm{C}$; reactivity measured over the range of $27^{\circ} \mathrm{C}$ to $593{ }^{\circ} \mathrm{C}$

- Primary helium pressure: $85 \%$ of maximum

- Power: $842 \mathrm{MWt}, 330 \mathrm{Mwe}$, as designed

- Physical parameters measured

o A large number of experiments have been performed in FSV and validated with various reactor physics codes with good agreement (see reference cited below). The experiments include data for

- Core criticality

- Axial flux and power distributions

- Temperature coefficients/defects 
- Control rod worths and shutdown margins

- Decay heat

- Destructive post-irradiation examination (PIE) of special fuel test elements to verify core design methods

- Experimental uncertainties provided? Yes. Uncertainties are available for temperature defect, control rod worth, power distribution, decay heat, and k-effective.

- Source of information used for this assessment

o General Atomics report DOE-HTGR-90314

o J. R. Brown et al., "Physics Testing at Fort St. Vrain - A Review," Nucl. Sci. Eng., 97, 104 (1987)

o J. W. Sterbentz, "Uranium Isotopics and Burnup Validation Study for the Fort Saint Vrain Reactor,” INEEL/EXT-02-00861, Idaho National Laboratory, November 2002

- Has a benchmark problem been developed from experimental data?

o No. However, calculated data have been compared to measurement data. Some of the results are contained in J. R. Brown's technical paper

- Applicability of data to V\&V of methods for the NGNP

o General Atomics has verified core performance with the modeling codes MICROX, 1DFX, BURGZ, GAUGE, FEVER, GATT, GARGOYLE, TWOTRAN, BUGTRI, ENDF/B-IV

o Experimental data (and particularly burnup data) would be useful to the evaluation of core design tools employed for the analysis of large power reactors; the presence of thorium fuel and the lack of a central reflector as in typical NGNP designs minimize the relevance of the data

- Prioritization of cases

o While all data would be pertinent to analysis of HEU/thorium fueled cores, all experimental data are GA proprietary

- Priority of experiment relative to others

o Ranked medium/high for prismatic-block-type cores 


\section{APPENDIX B.3}

\section{ASSESSMENT OF GGA HTGR CRITICAL EXPERIMENTS}

- Purpose of the experiment

o Provide necessary technical background information for the continued development of large high-temperature gas-cooled reactor (HTGR) systems; experimental data were utilized in evaluating cross-section data that were employed by Gulf General Atomic (GGA) for the design of HTGRs

- Description of facility and experimental configurations

o Core geometry: cylindrical geometry zone in split-bed core; integrated bed rectangular dimensions are $2.1 \mathrm{~m} \mathrm{x} 1.8 \mathrm{~m} \mathrm{x} 1.8 \mathrm{~m}$

o Fuel geometry: cylindrical fuel elements containing compacts of fuel

o Core materials

- Fuel type: Fuel compact contained highly enriched uranium (93 w/o U-235)-graphite in the form of $\mathrm{U}_{3} \mathrm{O}_{8}$

- Cladding or coating: Fuel tube is made of aluminum

- Moderator: graphite

- Coolant: N/A

- Conditions

o Power: zero power

- Physical parameters measured

o Core criticality

o Reactivity worths of materials

o Doppler coefficients

o Control rod worths

o Reactivity worth of burnable poisons

o Flux plots

- Experimental uncertainties available? Data uncertainties were provided in GGA technical report by Bardes

- Source of experimental data and information

o R. G. Bardes, et al., "Results of HTGR Critical Experiments Designed to Make Integral Checks on the Cross Sections in Use at Gulf General Atomic," GA-8468, GA Technologies, Inc., (Feb. 1968).

o D. Greneche, "An Analysis of some Gulf-HTGR Experiments by Apollo," DCPM 17/CEA-2, Oct 1973. (Obtained from OECD/NEA dataset on DRAGON Project Reports, from December 2003 IRhPE Meeting.) Contains results of CEA analysis of the criticals 
- Has a benchmark problem been developed from experimental data? Unknown. The GGA technical report contained significant information on the comparison of calculational models to the experimental data

- Applicability of data to V\&V of methods for the NGNP: The experiments were purposefully developed for validation of HEU fueled systems and are on that basis only marginally of interest to the NGNP for which LEU fuel is planned; additional experimental data would have to be obtained from General Atomics

- Prioritization of cases: All measurements are relevant

- Priority of experiment relative to others: core and fuel geometries are not same as for proposed NGNP design; the HTGR criticals however present clean experiments against which core analysis models and data could be validated and are therefore rated medium/high 


\section{APPENDIX B.4}

\section{ASSESSMENT OF HITREX-1 EXPERIMENTS}

- Purpose of the experiment

0 Measure reactor physics parameters of a low enriched uranium (LEU) system to provide data for checking the validity and accuracy of the calculational methods proposed for reactor design and operation

o Assessment of U-238 absorption arising from the multiple heterogeneity of the coated particle/fuel pin/lattice system

- Description of facility and experimental configurations

o Core geometry: hexagonal; effective core diameter $=$ unknown, active core height $=2 \mathrm{~m}$

o Fuel geometry: hexagonal blocks with fuel elements containing compacts in which coated fuel particles are embedded; teledial and annular fuel element designs were utilized

o Core materials

- Fuel type: LEU (up to 3.5\% U-235) in oxide form

- Cladding or coating: graphite material; fuel particles had a kernel and coatings of inner pyrolytic carbon, $\mathrm{SiC}$, and outer pyrolytic carbon; aluminum stringer and spacer plates were employed

- Moderator: graphite

- Coolant: N/A

- Conditions

o Power: zero power

- Physical parameters measured

o Control rod effects (reactivity worths and core perturbations)

o Flux and power distributions (interaction between pins, and power gradients at the core/reflector interface)

o $\mathrm{Pu}-239$ production and impact on fuel burnup and reactivity coefficients

o Fission rate of $\mathrm{Pu}-239$ relative to U-235

o Fast neutron graphite damage distribution

- Experimental uncertainties available? Data uncertainties were provided in report by Della-Loggia and Playle

- Source of experimental data and information:

o V.E. Della-Loggia, T.S. Playle, "Reactor Physics Measurements on the Zero Energy HTR Lattice HITREX-1 at CEGB Berkeley Nuclear Laboratories," D. P. Report 925, March 1975. (Obtained from CD containing OECD Dragon Project Reports, NEA-1726/01.)

- Has a benchmark problem been developed from experimental data? Unknown 
- Applicability of data to V\&V of methods for the NGNP: The experiments were purposefully developed for validation of LEU fueled systems and are useful for NGNP validation; detailed experimental data would have to be obtained from U.K. nuclear authorities

- Prioritization of cases: All measurements are relevant

- Priority of experiment relative to others: core and fuel geometries are not same as for proposed NGNP design; however, experiments are rated medium/high 


\section{APPENDIX B.5}

\section{ASSESSMENT OF HTLTR CRITICAL EXPERIMENTS}

- Purpose of the experiment

o Obtain experimental data that could be used for evaluating computational methods and cross sections utilized for analyzing plutonium-fueled hightemperature gas-cooled reactor systems

- Description of facility and experimental configurations

o Core geometry: core was located in graphite cube of $305 \mathrm{~cm}$ side

o Fuel geometry: graphite blocks containing $\mathrm{PuO}_{2}-\mathrm{ThO}_{2}$ in graphite matrix

o Core materials

- Fuel type: $\mathrm{PuO}_{2}$ is coated particle fuel with pyrocarbon coating; $\mathrm{ThO}_{2}$ fuel is uncoated

- Cladding or coating: Fuel matrix was contained in graphite block

- Moderator: graphite

- Coolant: Nitrogen gas was used to provide inert atmosphere to inhibit oxidation of the carbon moderator

- Conditions:

o Power: 0 to $2 \mathrm{~kW}$ power (most runs just barely at the critical level)

- Physical parameters measured:

o Core criticality

o Reaction rate traverses

o Material worths

$0 \quad \mathrm{k}_{\infty}$ variation with temperature

- Experimental uncertainties available? Unknown. Some experimental uncertainty data presented in paper by Newman

- Source of experimental data and information:

o D. F. Newman, "Temperature-Dependent $\mathrm{k}_{\infty}$ for a $\mathrm{ThO}_{2}-\mathrm{PuO}_{2} \mathrm{HTGR}$ Lattice," Nucl. Technol., 19, 66 (1973)

o http://www.hanford.gov/history/300area/300-8th.htm

- Has a benchmark problem been developed from experimental data? Unknown

- Applicability of data to V\&V of methods for the NGNP: The experiments were developed for validation of plutonium fueled HTGRs systems and hence only marginally of interest to the NGNP for which LEU fuel is planned

- Prioritization of cases: N/A

- Priority of experiment relative to others: Low 


\section{APPENDIX B.6}

\section{ASSESSMENT OF HTTR}

- Purpose of the experiment

o To establish and upgrade the technological basis for advanced hightemperature gas-cooled reactors

o To conduct various irradiation tests for innovative high-temperature research

- Description of facility and experimental configurations

o Core geometry: cylindrical; active core diameter $=2.30 \mathrm{~m}$, active core height $=2.9 \mathrm{~m}$

o Fuel geometry: Pin-in-block type fuel; a fuel rod consists of a graphite sleeve containing 14 fuel compacts; each fuel compact contains about 13,000 coated fuel particles embedded in a graphite matrix; a fuel assembly also contains burnable poison rods

o Core materials

- Fuel type: spherical $\mathrm{UO}_{2}$ kernels utilizing low enriched uranium (LEU); there are 12 different enrichments ranging from 3.4 to 9.9 w/o U-235

- Cladding or coating: TRISO particle configuration (porous carbon buffer, inner pyrolytic carbon layer, $\mathrm{SiC}$ layer, outer pyrolytic carbon layer)

- Moderator: graphite matrix in which TRISO particles are embedded

- Coolant: helium

- Conditions

o For initial criticality: zero power; core is at room temperature; the primary coolant system is filled with helium at normal atmospheric temperature and is not in operation during fuel loading

o For operation at power:

- Temperature: $395{ }^{\circ} \mathrm{C}$ at reactor inlet, $850{ }^{\circ} \mathrm{C}$ at reactor outlet $\left(850^{\circ} \mathrm{C}\right.$ is the rated operation temperature, and $950^{\circ} \mathrm{C}$ is the high temperature test operation temperature)

- Primary helium pressure: $4 \mathrm{MPa}$

- Power: $30 \mathrm{MWt}$

- Helium mass flow rate at full power: $12.4 \mathrm{~kg} / \mathrm{s}$

- Physical parameters measured

o Initial criticality for three configurations (annular and full-core loadings)

o Control rod worths

o Excess reactivity

o Scram reactivity

o Temperature coefficients of reactivity 
o Neutron flux distribution measurements

- Experimental uncertainties available? Yes.

- Source of experimental data and information

o "Evaluation of High Temperature Gas Cooled Reactor Performance: Benchmark Analysis Related to the HTTR and HTR-10," IAEA TECDOC-1382, Vienna, 2003.

o N. Nojiri et al., "Benchmark Problem's Data for HTTR's Start-up Core Physics Experiments," JAERI Memo 10-005, January 1998.

o "Characteristics of HTTR's Startup Physics Tests," page 333 of "High Temperature Gas Cooled Reactor Technology Development," IAEA TECDOC-988, Vienna, 1997.

- Has a benchmark problem been developed from experimental data? Yes.

- Applicability of data to V\&V of methods for the NGNP

o The HTTR core physics data are highly desirable for the evaluation of code suites developed for analysis of the block-type NGNP

- Prioritization of cases: All initial core physics tests are relevant

- Priority of experiment relative to others: HTTR has high relevance to NGNP/VHTR block-type analysis 


\section{APPENDIX B.7}

\section{ASSESSMENT OF PEACH BOTTOM HTGR}

- Purpose of the reactor

o Experimental power reactor that provided technical and cost data to U.S. utilities on the feasibility of large HTGRs

- Description of facility and experimental configurations

o Core geometry: cylindrical; active core diameter $=2.8 \mathrm{~m}$, active core height $=2.3 \mathrm{~m}$

o Fuel geometry: Reactor employed cylindrical fuel elements

o Core materials

- Fuel type: Mostly highly enriched uranium (93 w/o U-235 intimately mixed with graphite and thorium (thorium to uranium mass ratio $\sim 6.2$ ); $(\mathrm{Th}, \mathrm{U}) \mathrm{C}_{2}$-BISO

- Cladding or coating: graphite

- Moderator: graphite matrix

- Coolant: helium

- Conditions

o For operation at power:

- Temperature: $345^{\circ} \mathrm{C}$ at reactor inlet, $725^{\circ} \mathrm{C}$ at reactor outlet

- Primary helium pressure: 24 bar

- Power: $40 \mathrm{MWe}$ and $115 \mathrm{MWt}$

- Physical parameters measured

o $\mathrm{k}_{\text {eff }}$

o Power distributions

o Control rod worths

o Temperature coefficients/defects

- Experimental uncertainties provided? General Atomics (GA) would have pertinent data

- Source of information used for this assessment

o C. A. Preskitt et al., "Interpretation of Pulsed-Source Experiments in the Peach Bottom HTGR," Nucl. Sci. Eng., 29, 283 (1967).

o "Critical Experiments and Reactor Physics Calculations for Low-Enriched High Temperature Gas-Cooled Reactors," IAEA TECDOC-1249, Vienna, 2001.

o P. R. Kasten, “Overview of Gas-Cooled Reactors," Vol. 1 of Short Course on Modular High Temperature Gas-Cooled Reactors, University of Tennessee, August 1989. 
- Has a benchmark problem been developed from experimental data? No. However, experimental data were compared to calculated ones in the paper by Preskitt

- Applicability of data to V\&V of methods for the NGNP: The Peach Bottom HTGR experimental data provides an excellent database for the evaluation of HEU/thorium systems; however, this fuel system is quite different from that considered for the NGNP; additionally, the reactor fuel element and form are quite different from those planned for the NGNP

- Prioritization of cases: Not much detailed information was located to determine data of interest

- Priority of experiment relative to others: low for prismatic block-type NGNP cores 


\section{APPENDIX B.8}

\section{ASSESSMENT OF PEACH BOTTOM CRITICAL EXPERIMENTS}

- Purpose of the experiment

o Support development of the HTGR and its first prototype at Peach Bottom by providing confidence in the core calculational techniques and nuclear data used for core analysis

- Description of facility and experimental configurations

o Two types of experiments: test-lattice and HTGR mockup

o Core geometry: cylindrical; core diameter $=1.5 \mathrm{~m}$, core height $=1.2 \mathrm{~m}$

o Fuel geometry: block type fuel or annular or cylindrical tube fuel

o Core materials

- Fuel type: $\mathrm{HEU}(93 \%)$ in $\mathrm{U}_{3} \mathrm{O}_{8}$ and thorium intimately mixed with graphite (in compact form)

- Cladding or coating: graphite tube

- Moderator: graphite

- Coolant: N/A

- Conditions

o Power: zero power

- Physical parameters measured

o Criticality state

o Doppler and isothermal temperature coefficients

o Evaluation of thorium resonance integral

o Flux distribution

o Control rod worth

o Neutron flux distribution measurements

- Experimental uncertainties available? No source of information on this item

- Source of experimental data and information

o R. G. Bardes et al., "High Temperature Gas Cooled Reactor Critical Experiment and Its Application," Proc. IAEA Symp. Exponential and Critical Experiments, Amsterdam, Netherlands, September 2-6, 1963, conference paper SM-42/37, International Atomic Energy Agency (1963)

- Has a benchmark problem been developed from experimental data? Unknown

o Comparison of calculation to measurement for multiplication factors as functions of temperature, resonance captures, Doppler coefficients, and activation traverses were provided in technical paper by Bardes et al. 
- Applicability of data to V\&V of methods for the NGNP: The experiments were purposefully developed for validation of HEU/thorium fueled systems and are not directly useful for NGNP validation

- Prioritization of cases: The two experiment sets form a complete basis for assessing HEU/thorium fuel systems

- Priority of experiment relative to others: low 


\section{APPENDIX B.9}

\section{ASSESSMENT OF SHE}

- Purpose of the experiment

o Critical facility for experiments on low enriched uranium (LEU) systems to support the development of high-temperature reactors

- Description of facility and experimental configurations

o Core geometry: hexagonal; flat-to-flat dimension is $2.4 \mathrm{~m}$, core height $=$ $2.4 \mathrm{~m}$; core composed of two hexagonal prismatic sections (split-table)

o Fuel geometry: fuel rods containing fuel disks

o Core materials

- Fuel type: homogeneous mixture of $20 \%$ enriched $\mathrm{UO}_{2}$ and pure graphite (graphite to $\mathrm{UO}_{2}$ ratio of 10:1)

- Cladding or coating: graphite

- Moderator: graphite

- Coolant: N/A

- Conditions

o Power: zero power critical

- Physical parameters measured

o Critical masses

o Kinetics parameters

o Reactivity worths of control and burnable poison rods

o Reactivity temperature coefficients

o Power distributions

- Experimental uncertainties available? JAERI would have these data

- Source of information used for this assessment:

o Y. Kaneko, "Reactor Physics Research Activities Related to the Very High Temperature Reactor in Japan," Nucl. Sci. Eng. 97, 145 (1987).

- Has a benchmark problem been developed from experimental data? Unknown; However, comparisons of calculated versus measured $\mathrm{k}_{\mathrm{eff}}$, critical mass, and $\beta_{\mathrm{eff}}$ were presented in Kaneko's paper

- Applicability of data to V\&V of methods for the NGNP

o In light of the differences between the fuel design of the SHE configuration and that of proposed NGNP, this experiment is rated medium/high; however, it would be a useful addition to the set of cases evaluated for the NGNP as it employs higher enrichment (20 w/o U-235) than those in the VHTRC experiments 
- Prioritization of cases

o All measurements are of similar importance

- Priority of experiment relative to others

o SHE experimental data are rated medium/high for the NGNP 


\section{APPENDIX B.10}

\section{ASSESSMENT OF VHTRC}

- Purpose of the experiment

o Critical facility for experiments on low enriched uranium (LEU) systems for support of the development of high-temperature reactors

- Description of facility and experimental configurations

o Core geometry: hexagonal; flat-to-flat dimension was $2.4 \mathrm{~m}$, core height = $2.4 \mathrm{~m}$; core composed of two hexagonal prismatic sections (split-table)

o Fuel geometry: hexagonal fuel blocks with flat-to-flat distance of $30 \mathrm{~cm}$; Fuel rods were inserted in holes in the graphite block, each rod containing fuel compacts in which fuel particles are embedded

o Core materials

- Fuel type: spherical low enriched uranium(2-6 w/o U-235) in oxide form

- Cladding or coating: BISO particle configuration with two carbon layers

- Moderator: graphite matrix in which particles were embedded

- Coolant: N/A

- Conditions

o Power: zero power critical

- Physical parameters measured

o Core criticality

o Control rod and burnable poison worths

o Isothermal temperature defects/coefficients

o Flux distributions

o Kinetics parameters

- Experimental uncertainties available? JAERI would have these data

- Source of information used for this assessment

o H. Yasuda, et al., "VHTRC Temperature Coefficient Benchmark Problem," JAERI-Data/Code 94-103, Japan Atomic Energy Research Institute, October 1994

o "Critical Experiments and Reactor Physics Calculations for Low-Enriched High Temperature Gas-Cooled Reactors," IAEA TECDOC 1249, Vienna, 2001

- Has a benchmark problem been developed from experimental data? Yes. Results of comparison of calculation to measurement results obtained by different international institutions are provided in IAEA TECDOC 1249; core dimensions and descriptions are provided in the report by Yasuda 
- Applicability of data to V\&V of methods for the NGNP

o Experimental data (and particularly burnup data) would be useful to the evaluation of core design tools employed for the analysis of the block-type NGNP; however, the enrichment in the VHTRC experiment is lower than that for the block-type NGNP

- Prioritization of cases

o The two benchmark cases VH1-HP and VH1-HC are rated high

- Priority of experiment relative to others

o VHTRC experimental data is highly relevant to the block-type NGNP 